\title{
The South Tasman Rise Arrangement of 2000 and other Initiatives on Management and Conservation of Orange Roughy
}

\author{
Erik Jaap Molenaar* \\ Netherlands Institute for the Law of the Sea (NILOS), Utrecht \\ University
}

\begin{abstract}
The exceptional vulnerability of the fish species orange roughy has been amply demonstrated by the collapse of various relatively new fisheries where management and conservation measures werc absent, inadequate or simply 100 late. Each of the three case studies of orange roughy fisheries discussed in this article has an inherent international dimension as they concern discrete high seas stocks, straddling stocks or stocks on whose categorisation states disagree. The case studies illustrate the more general shortcomings of the international legal framework for the management and conservation of marine living resources. but also specifically for vulnerable species like orange roughy. Crucial to long-term sustainable management are the issues of participation in regional fisheries management mechanisms or negotiation processes to establish them, as well as the allocation of fishing opportunities thereunder. Possibly, the role of marine scientific research can be further enhanced in relation to the categorisation of stocks and the concept of zonal attachment.
\end{abstract}

\section{Introduction}

Orange roughy (Hoplostethus atlanticus Collett) is a bright orange fish that is commercially interesting because of its good taste and relative ease of processing. It is a demersal deep-sea species found on the continental slope at depths of approximately $1,000-2,000$ metres. ${ }^{1}$ Orange roughy occur in low densities on the

* The author would like to acknowledge the generous assistance of, and/or comments by, W. Emerson, M. Gianni, J. Harford, D. Miller, J.L. Olsen, A.G. Oude Elferink, G. Rohan, A. Serdy, M. Tsamenyi and $\mathrm{W}$. Wolff on an earlier version of this article. The author naturally remains responsible for the current text.

1 This and other scientific information on orange roughy is based on www.affa.gov.au:80/ fisheries/organisation/international_sect.html and www.affa.gov.au:80/fisheries/fishfacts/ ffl1.html (accessed 8 August 2000).

THE INTERNATIONAL JOURNAL OF MARINE AND COASTAL LAW, Vol 16, No 1

(C) Kluwer Law International, 2001 
flat sea-bed but, during spawning season, are also found in large aggregations at specific locations, often around seamounts, pinnacles and canyons. These large aggregations are extremely attractive for fishing operators that have the vessels and equipment suitable for deepwater operations and the special skills required for manoeuvring their nets around spiny pinnacles and in steep canyons.

Orange roughy exist in both hemispheres. In the northern Atlantic Ocean their range of distribution extends from north-west of the British Isles southwards to off north-west Africa and, in the southern Atlantic Ocean, off Namibia. Pockets also exist in the western Mediterranean Sea. A large range of distribution encompasses the ridges of the southern Indian Ocean from Africa to Australia, the Southern Ocean and the south-west Pacific Ocean. Due to their deep-sea habitats and their spawning and aggregating behaviour, considerable exploration is commonly needed to locate aggregations.

The species has a long life-span, according to some scientists possibly up to 150 years. Maturity is thought to occur between the ages of 20-32 when the fish are around $28-32 \mathrm{~cm}$ long and weigh between 500 and 800 grams. The average size taken by fishing operations is about $35-40 \mathrm{~cm}$, with an average weight of $1-2$ kg. Their slow growth, low recruitment, long period before reaching maturity and relative ease of being fished are all factors that underscore the need for appropriate and speedy management and conservation measures. Witness to the vulnerability of the species are various fisheries that collapsed after only a short period of large-scale fishing activity, for example the South East Fishery within the Australian Fishery Zone $(A F Z)^{2}$ and the fishery on the Louisville Ridge, situated on the high seas east of New Zealand. ${ }^{3}$ Very recently, the same seems to have occurred for the stock on the Challenger Plateau (see below).

For deep-sea species like orange roughy, there is a relatively high chance that its range of distribution will in part or in its entirety cover the high seas. The implicit international dimension therein brings with it obvious obstacles to swift agreement on, and adoption of, conservation and management measures. In the case of new fisheries for stocks that occur partly or entirely on the high seas,

2 Even though Australia proclaimed an exclusive economic zone (EEZ) in 1994, it continues to use an AFZ for fisheries regulation. Certain parts within the Australian EEZ are not at the same time also part of the AFZ (see section 11 of the Fisheries Management Act 1991 (Cth), at www.austlii.edu.au/au/legis/cth/consol_act/).

3 Catches taken in the AFZ peaked in $1 \overline{9} 90$ with 46,000 tonnes while current catches are around 5,000 tonnes. Annual catches and TACs for New Zealand's orange roughy fisheries continuously decrease as well, with a peak in 1988-89 of around 51,000 tons while it was around 17,000 tons in 1997-98 (see www.fish.govt.nz). Concern for the status of the orange roughy stock on the Chatham Rise led Greenpeace New Zealand to apply for a review of a decision made by the Minister of Fisheries (Greenpeace New Zealand Inc. v Minister of Fisheries, High Court of New Zealand, Judgment of 27 November 1995). See also the concern expressed by Dr Maguire in relation to exploitation of deep water species in the North Atlantic (Report of the 17th Annual Meeting (1998) of the North-East Atlantic Fisheries Commission (NEAFC), p. 2, para. 6). Despite pleas from various NGOs, specific management measures were still not adopted at the 19th Annual Meeting (2000), except in relation to reporting routines. 
there is an additional problem as there is often no mechanism for co-operation in place, and the fishery is therefore unregulated. With the continuously increasingly pressure on the ocean's resources, the exploitation of a growing range of species is likely to become economically interesting and the exploration for such species more intense. In certain circumstances, there may even be risk of loss of marine biodiversity. While these factors underscore the need to adopt conservation and management measures as expeditiously as possible, the international legal regime for the conservation and management of transboundary stocks may often be inadequate for dealing with these situations.

This article deals with three situations where stocks of orange roughy occur partly or wholly beyond maritime zones under national jurisdiction. The first stock is located in the South Tasman Rise, an area south of Tasmania, the second on the Challenger Plateau east of New Zealand and the third in the southern Indian Ocean. While the international dimension of these case studies is obvious, this is not to say that each is governed by the same set of rules of international law or that management approaches should be similar if the applicable law is the same. As these case studies will show, the choice of management approaches is also strongly influenced by extra-legal elements. As regards the applicable law, one question that will arise frequently is whether a situation is governed primarily by the LOS Convention ${ }^{4}$ or by both the LOS Convention and the 1995 Fish Stocks Agreement. ${ }^{5}$ As is obvious from the full title of the latter agreement, it applies in principle only to straddling fish stocks and highly migratory fish stocks. Obviously, other rules or principles of international law, such as the precautionary approach, may be applicable as well.

The bulk of the article is devoted to the 2000 "Arrangement Between the Government of Australia and the Government of New Zealand for the Conservation and Management of Orange Roughy on the South Tasman Rise" (2000 STR Arrangement), the text of which is appended. ${ }^{6}$ The Arrangement is analysed in light of the applicable international law and ongoing efforts in the progressive development of the international law in this field. ${ }^{7}$ The case studies of

United Nations Convention on the Law of the Sea, Montego Bay, 10 December 1982, in force 16 November 1994, (1982) 21 ILM 1245. At 16 October 2000, 134 states and the European Community (EC) were parties to the LOS Convention.

5 Agreement for the Implementation of the Provisions of the United Nations Convention on the Law of the Sea of 10 December 1982 Relating to the Conservation and Management of Straddling Fish Stocks and Highly Migratory Fish Stocks, New York, 4 August 1995, not in force, UN Law of the Sea Bulletin, 29 (1995), p. 25. At 16 October 2000, there were 28 states parties ( 30 needed).

6 Signed for New Zealand on 17 February 2000 and for Australia on 25 February 2000. The Arrangement has been lodged with the Fisheries Department of the Food and Agriculture Organization (FAO) in accordance with para. 35 of the Arrangement. The Arrangement took effect on 1 March 2000 (para. 33).

7 Inter alia, the work on the International Plan of Action (IPOA) on illegal, unreported and unregulated (IUU) fishing that is currently carried out within the FAO. Between 2 and 6 October 2000, a Technical Consultation on IUU Fishing was held at the FAO in Rome. The 
the Challenger Plateau and the southern Indian Ocean are dealt with less comprehensively in separate sections. Finally, the article ends with some conclusions.

\section{South Tasman Rise}

\section{Introduction}

The South Tasman Rise (STR) is an area of the Australian continental shelf south of Tasmania that extends from within the AFZ into adjacent high seas. Late 1997 saw a sudden intensification of fishing for orange roughy in the high seas section of the South Tasman Rise. With more and more Australian and New Zealand vessels entering the fishery, the need for regulatory action became urgent. This led to the adoption in 1998 of the "Arrangement Between the Government of Australia and the Government of New Zealand for the Conservation and Management of Orange Roughy on the South Tasman Rise" (1998 STR Arrangement). ${ }^{8}$

All fishing under the 1998 STR Arrangement was conducted as part of the "Program of scientific research", to which the main paragraphs of the Arrangement were devoted. The primary objective of this research was to "provide clear information on the stock structure and relationship between orange roughy taken on the high seas and orange roughy occurring within the AFZ". 9 The research was to rely exclusively on commercial operators. Although not objectionable as such, ${ }^{10}$ these operators did not gather extensive data. ${ }^{11}$ As the quotas were reached very quickly and had yielded little useful scientific data, a specific directed programme of 150 tonnes for each of the two states was decided on and implemented. ${ }^{12}$

Cont.

Report of the Expert Consultation on Illegal, Unreported, and Unregulated Fishing Organized by the Government of Australia in Co-operation with FAO, Sydney, Australia, 15-19 May 2000 (information, report and papers at www.affa.gov.au/ecoiuuf) was effectively accepted as a first draft of the IPOA. As the first Technical Consultation was unable to finalize the IPOA, a Second Technical Consultation is scheduled for 22-23 February 2001, prior to the Meeting of the Committee on Fisheries (COFI). Australia's pro-active role in this undertaking seems partly prompted by the unregulated fishery for orange roughy in the South Tasman Rise (see Report of the First Meeting of the United Nations Open-Ended Informal Consultative Process on Oceans and the Law of the Sea (UNICPOLOS), UN Doc. A/55/274, para. 55 (text available at www.un.org/Depts/los)).

8 Signed on 12 January 1998 and 18 February 1998 respectively. Text available at www.dfat.gov.au/geo/new_zealand/selected_docs.html.

9 Para. 2 of the 1998 STR Arrangement. See àlso the preamble. Further discussion will takc place in the scction entitled "Scientific Research and the Categorisation of Stocks" below.

10 In certain circumstances, it may in fact be too expensive to have dedicated research vessels.

11 Para. 5 of the 1998 STR Arrangement lists seven aspects on which data could be gathered: catch by location, length frequency, age structure, reproductive stage, morphometrics, stocks genetics and otolith structure.

12 "Joint Australian/New Zealand Research on Straddling Orange Roughy Stocks: South Tasman Rise. Summary of Findings and Discussion of a Workshop held at Wellington", 16-17 February 1999 , p. 1. 
The "Program of scientific research" was carried out through a total allowable catch (TAC) of 2,100 tonnes for the duration of the 1998 STR Arrangement. The allocation of national quotas was based on 1997 catch figures and could only be set after the adoption of the 1998 STR Arrangement. A ratio of approximately 4:1 in favour of Australia was finally agreed upon. Co-operation under the 1998 STR Arrangement proceeded satisfactorily, despite the fact that quotas were exceeded. ${ }^{13}$ The Arrangement was only intended to last from 1 March 1998 until 28 February 1999, but the parties agreed to meet in February 1999 to review the Arrangement and to consider anew conservation and management measures for orange roughy on the high seas area of the South Tasman Rise. ${ }^{14}$ Despite the many rounds of negotiation that took place in early 1999, the Arrangement could not be renewed for the 1999-2000 season. Although at officials' level it was agreed to set an annual TAC of 2,400 tonnes, ${ }^{15}$ shared on a $3: 1$ basis, ${ }^{16}$ the TAC had already been exceeded before this agreement could be put into writing. ${ }^{17}$ Subsequently, both states closed the area to their operators/vessels until 29 February 2000.

Until that time, the South Tasman Rise fishery had essentially been a bilateral issue between Australia and New Zealand. This came to an end in June 1999 when four vessels, three registered in South Africa and one in Belize, were sighted fishing in the high seas area of the South Tasman Rise. Collectively, the vessels were thought capable of catches that would have exceeded 2,400 tonnes. Severe diplomatic pressure exerted mainly by Australia ultimately led the South African

13 Although both states exceeded their quotas, this was considerably more substantial in the case of New Zealand. This overcatch has finally been resolved by the side-arrangement to the 2000 STR Arrangement, as referred to in the main text accompanying note 29 below. This settlement of outstanding differences also covered Australian catches in the period between the adoption and entry into force of the 1998 STR Arrangement. See 1998 STR Arrangement, paras 18-20.

15 The increase in the TAC is explained by the inclusion of the 300 tonnes that were used for dedicated research in the 1998-99 season.

16 This ratio departs from the approximate 4:1 ratio mentioned above, which was based on 1997 catch figures, in particular the catch between September and November 1997. The new ratio was accepted in recognition of Australian catches in February 1997 and the inability for New Zealand to build a catch history in mainly December 1997. No recognition seems to have been given to other arguments besides catches, e.g. arguments based on coastal state sovereign rights in the EEZ or zonal attachment.

17 Australia closed its fishery on 27 April 1999 (verified catch 1,724 tonnes) but New Zealand only withdrew its vessels after the Arrangement on the 1999-2000 season was renewed on 2 June 1999 (approximate catch 1,670 tonnes). By then New Zealand's vessels had already caught almost three times what it would have been entitled to under the non-finalised agreement for the 19992000 season (information partly obtained from www.afma.gov.au/fisheries/fisheries $\% 20 \mathrm{index} /$ strf.htm, accessed 9 August 2000). New Zealand observed that it had to await the adoption of the 1999 Fisherics (South Tasman Rise Orange Roughy Fisheries) Regulations (SR 1999/142, 2 June 1999) to enable it to pull out its vessels. These regulations essentially prohibit the taking and landing of orange roughy caught in the South Tasman Rise (see also the section entitled "Classification of the 2000 STR Arrangement and Other Alternatives to Flag State Jurisdiction" below). 
Government to withdraw its vessels from the area while the Belizean Government deregistered its vessel. All vessels left the South Tasman Rise. These events heightened awareness for the need to pay more attention to third states, inter alia by ensuring that arrangements for the orange roughy fishery on the South Tasman Rise would be given wider publicity. The 2000 STR Arrangement that was agreed on early in 2000 and took effect on 1 March 2000 , clearly reflects this. ${ }^{18}$

The 2000 STR Arrangement consists of a preamble with eight paragraphs while the body of the Arrangement is made up of 36 paragraphs. Some of these paragraphs have been more or less copied from the 1998 version, which contained 23 paragraphs. ${ }^{19}$ The following discussion will address the main components of the 2000 STR Arrangement under the headings: quotas and implementation, scientific research and the categorisation of stocks, allocation, general approach towards third countries, port state jurisdiction and the classification of the 2000 STR Arrangement and other alternatives to flag state jurisdiction.

\section{Quotas and Implementation}

Paragraph 5 of the 2000 STR Arrangement lays down a new bilateral compromise on fishing opportunities by allocating 75 per cent of the TAC to Australia and 25 per cent to New Zealand. This is the same ratio as under the non-finalised agreement for the 1999-2000 season and presumably based on identical considerations. ${ }^{20}$ Pursuant to paragraph 3 , the precautionary TAC is fixed at 2,400 tonnes for each season, even though paragraph 4 allows this to be adjusted after mutual agreement. ${ }^{21}$ As the 2000 STR Arrangement is not explicitly intended to have a limited duration, this compromise reflects a wish for stability and would restrict negotiation on allocations as much as possible. Nevertheless, paragraph 6 acknowledges that the ratio of 3:1 can be changed and, of course, any party could unilaterally decide to end the Arrangement in accordance with the terms of paragraph 33.22

18 See in particular the section entitled "General Approach to Third Countries" below.

19 E.g.: para. 2 (was para. 8 in the 1998 Arrangement), para. 16 (was more or less para. 11 in the 1998 Arrangement), para. 19 (was para. 10 in the 1998 Arrangement), paras 24 and 25 (were more or less paras 16 and 17 in the 1998 Arrangement).

20 See note 16 above.

21 While para. 3 uses "precautionary" TAC, all other paragraphs simply use "TAC". The qualification "precautionary" in para. 3 therefore probably means that the precautionary approach was applied when determining the TAC of 2,400 tonnes. Moreover, the reference to the precautionary approach in the preamble would imply that it will also be applied when adjusting the TAC in accordance with para. 4, even though that provision does not use the term "precautionary". At any rate, the Arrangement essentially uses only one type of TAC; not two or more.

The condition of 12 months' advance notice in para. 33 also fosters stability. Para. 33 might have to be redrafted in case third countries would be included in the Arrangement pursuant to para. 32. 
Paragraph 13 provides that "[a]ny fishing undertaken within the scientific research program will be taken within the TAC". Due to Australia and New Zealand's involvement in the Southern Bluefin Tuna (Provisional Measures) cases, ${ }^{23}$ this is more than just a departure from the approach under the 1998 STR Arrangement where all fishing was effectively labelled as scientific research. The main argument in these cases before the International Tribunal for the Law of the Sea (ITLOS) was that Japan had unilaterally set a TAC for its own experimental fishing program (EFP). This TAC would be fished in addition to the quota that would normally be allocated to Japan within the framework of the CCSBT Convention. ${ }^{24}$ The ITLOS Order in these cases confirmed that Japan could not act unilaterally in this respect. ${ }^{25}$ Paragraph 13 of the 2000 STR Arrangement is therefore consistent with that Order. In the merits phase of this dispute, however, the Arbitral Tribunal decided that it was without jurisdiction on the merits and consequently revoked the provisional measures that had been in force due to the ITLOS Order. ${ }^{26}$

Paragraph 1 contains a number of definitions with relevance for the allocation issue. The definition of "season" has been included as a consequence of the permanent character of the Arrangement. Innovatory is the "annual catch limit", which is determined in accordance with paragraphs 7 and 8. These paragraphs allow the annual catch limit to vary from the quotas established in accordance with paragraphs 5 and 6 (described above) if the parties have fished either more or less than their previous season's allocation. In case the catch fell short of the previous annual catch limit, this entitles a party to a compensation of up to 5 per cent of its quota in the previous season. ${ }^{27}$ Even more interesting is the other situation, namely, where previous catches are in excess of allocations, as this happens frequently in marine capture fisheries. Paragraph 7(b) provides that excess catches are debited on a 1:1 ratio for the first 100 tonnes and on a 1:2 ratio for each tonne of excess catch thereafter. Moreover, paragraph 8 ensures that, if necessary, more than one season can be used to adjust the annual catch limit as a result of excess catches. ${ }^{28}$

This mechanism was primarily developed as a consequence of the disagree-

Southern Bluefin Tuna Cases (Nos. 3 and 4) (New Zealand v Japan; Australia v Japan), Requests for Provisional Measures, Order of 27 August 1999, www.un.org/Depts/los.

24 Convention for the Conservation of Southern Blucfin Tuna, Canberra, 10 May 1993, in force 20 May 1994, www.home.aone.net.au/ccsbt. The extraordinary situation was of course that the last mutually agreed TAC and allocation stemmed from 1997. Order, para. $90(1)(c)$ and $(d)$

26 Southern Bluefin Tuna case (Australia and New Zealand v Japan), Arbitral Tribunal Constituted under Annex VII of the United Nations Convention on the Law of the Sea, Award on Jurisdiction and Admissibility of 4 August 2000, www.worldbank.org/icsid, para. 72(1) and (2). Japan might therefore unilaterally decide to resume its EFP.

27 No compensation is possible if "the TAC for that season is less than the TAC for the previous season", as such compensation would interfere with the need for smaller catches (a reduced $\mathrm{TAC}$ ).

Of course, any party could end the Arrangement in accordance with para. 33. 
ment between Australia and New Zealand regarding past fishing for orange roughy in the South Tasman Rise. As part of the adoption of the 2000 STR Arrangement, Australia and New Zealand agreed to settle their outstanding differences in a side-arrangement which provides for the reimbursement of 640 tonnes by New Zealand. ${ }^{29}$ This will be accommodated by deducting 100 tonnes from New Zealand's quota each year for a period of six years, with 40 tonnes to be deducted the following year. Reimbursement on a ratio of $1: 2$ is designed to discourage over-fishing and will also give the stock a better chance of recovery from previous over-fishing. The latter aspect follows from the fact that, if annual catch limits are exceeded, this implies that the combined annual catch limits for the coming season will be lower than the TAC. The difference will be larger due to the 1:2 ratio. In light of the specific characteristics of orange roughy, it remains to be seen if this graded reimbursement scheme will be sufficient for the stock's recovery. Worth mentioning here is that reimbursement or "payback" was, and still is, one of the prominent issues in the dispute that Australia and New Zealand have with Japan over the latter state's unilateral EFP for southern bluefin tuna. ${ }^{30}$ The reimbursement approach of the 2000 STR Arrangement is obviously not applicable here, but it seems likely that some kind of penalty ratio would be appropriate.

Numerous provisions in the Arrangement bear witness to the importance of compliance. The preamble already refers to the need to implement the Arrangement, while paragraphs 10 and 11 address the issue more thoroughly. ${ }^{31}$ Other relevant provisions include the prohibition of high seas fishing without prior authorisation (para. 2), ${ }^{32}$ the various ways in which the fishery is to be monitored (paras $20-23)^{33}$ and the very regular exchange of all relevant catch and effort information (paras 17 and 18).

In part based on a press statement of 7 February 2000 by W. Truss, Australian Minister for Agriculturc, Fisheries and Forestry (tcxt at www.affa.gov.au:80/affa/pr/releases/truss/00/ 012 wt.html, accessed 15 August 2000). See also note 13 above.

This despite the fact that Japan already offered some payback (sec para. 40(c) of the Award in the Southern Bluefin Tuna case, note 26 above).

31 The explicit obligation to close the fishery in para. 11 is probably a direct result of past experiences. The mandatory wording of paras 10 and 11 of the 2000 STR Arrangement contrasts with the phrase "will use their best endeavours" in para. 20 of the 1998 STR Arrangement. This gives cffect to Art. 18(3)(a) of the 1995 Fish Stocks Agreement.

33 These provisions are in general much more specific and stringent than their predecessors in paras 12-15 of the 1998 STR Arrangement. However, the placement of observers is now only needed "at a lcvel of coverage sufficient" (para. 21 of the 2000 STR Arrangement) whereas dockside inspection is to have "a level of [sufficient] coverage jointly decided by the Parties" (para. 22 of the 2000 STR Arrangement). The prohibition of transhipment "within waters under their national jurisdiction or to or from their fishing vessels or fish carriers" (para. 23) is also new. Both states therefore take the view that such an approach is within their jurisdiction as a flag state and a coastal state. The present author shares this view (see E.J. Molenaar and M. Tsamenyi, "Satellite-Based Vessel Monitoring Systems for Fisheries Management. International Legal Aspects", (2000) 15 International Journal of Marine and Coastal Law 65-109 at 79-81 and 87-93). 
Finally, paragraph 34 obliges the parties to "consult at the request of either of them with a view to resolving matters amicably and without unreasonable delay". This is an appropriate provision in an instrument that the signatory states do not intend to have treaty status ${ }^{34}$ and does not prejudice the applicability of Part XV of the LOS Convention or Part VIII of the 1995 Fish Stocks Agreement.

\section{Scientific Research and the Categorisation of Stocks}

From the moment that Australia and New Zealand were both involved in the orange roughy fishery in the South Tasman Rise, there has been disagreement over the categorisation of the stock(s). It is perhaps no surprise that Australia, as the only relevant coastal state, argues that it concerns a single straddling stock. New Zealand has consistently rejected this argument by taking the view that it concerns two distinct stocks (one in the AFZ and one on the high seas). The underlying issue is whether Australia would be entitled to coastal state rights over straddling stocks, or if Australia, just like New Zealand, can rely only on its flag state right to engage in fishing on the high seas. ${ }^{35}$

The categorisation of stocks has of course broader implications than "mere" allocation. Nevertheless, it should be mentioned here that annual catches of orange roughy in the AFZ section of the South Tasman Rise have, up until now, not been much larger than 68 tonnes. ${ }^{36}$ As will be discussed below, this circumstance has consequences for the issue of allocation. It is sufficient to note here that these catches are quite insubstantial in comparison with the determined TACs under the 1998 and 2000 STR Arrangements. The fact that Australia has nevertheless been allocated the lion's share of the TAC must therefore be mainly attributed to its historical catches as a flag state which, it should be observed, only commenced in 1997.

The two states tried to resolve their disagreement through the "Program of scientific research" under the 1998 STR Arrangement, which was to focus on clarifying the categorisation of the stock(s). ${ }^{37}$ This attempt was hampered by the fact that neither the LOS Convention nor the 1995 Fish Stocks Agreement provides a definition for "straddling fish stocks". At the negotiations of the 1995

See note 111 below.

35 Art. 116 of the LOS Convention. The precise scope of these coastal state rights would then be a secondary issue, inter alia, dependent on the applicability of the 1995 Fish Stocks Agreement.

36 This concerns the period 1986-99, with significant catches only in 1990 and 1997. However, no genuine exploration has taken place within the AFZ. The only regulatory measure applying to orange roughy in that part of the South Tasman Rise which also forms part of the AFZ is a socalled "trigger" of 500 tonnes, meaning that the neccssary management measures will be taken if annual catches exceed 500 tonnes (information kindly obtained from J. Harford, Australian Fisheries Management Authority (AFMA)).

37 See para. 2, partly cited in the beginning of the introduction to this article. 
Agreement, several delegations felt a need for such a definition. ${ }^{38}$ Some delegations proposed that the wording of Article 63(2) of the LOS Convention should be used, ${ }^{39}$ whereas other delegations proposed other approaches or definitions ${ }^{40}$ It is not unlikely that the very complex definitions such as those proposed by the Russian Federation ${ }^{41}$ ultimately made the Conference decide that it was better to avoid definitions altogether and leave the matter to be resolved at the (sub)regional level. ${ }^{42}$

The lack of definitions is not limited to straddling stocks. It also concerns the shared (or joint) stocks referred to in Article 63(1) of the LOS Convention, which occur within two or more EEZs. As a consequence of the absence of definitions, there is no implicit definition of discrete stocks that are confined solely to the high seas or to a single state's EEZ. Problems of definition also exist with respect to anadromous stocks, catadromous stocks and sedentary species..$^{43}$ In contrast, the situation for marine mammals and highly migratory fish stocks or species seems much less liable to be disputed. ${ }^{44}$

The research carried out under the 1998 STR Arrangement finally led Australia and New Zealand to agree that the orange roughy stock in the South Tasman Rise should be managed as a single discrete stock. The stock is therefore managed separately from other stocks of orange roughy in locations other than the South Tasman Rise. At the same time, however, the states disagreed as to whether the stock is also a straddling stock. ${ }^{45}$ Without a legal definition of "straddling stocks", guidance must first of all be found in Article 63(2) of the LOS Convention, which relates to stocks that "occur both within the exclusive economic zone and in an area beyond and adjacent to the zone". A straddling stock within the meaning of Article 63(2) simply has to "occur" in both zones

See UN Doc. A/CONF.164/L.1 (issue 1), submitted by Peru and UN Doc. A/CONF.164/L.12 (issue 1), submitted by Cuba (reprinted in J.-P. Lévy and G.G. Schram, United Nations Conference on Straddling Fish Stocks and Highly Migratory Fish Stocks - Selected Documents (The Hague, Boston and London, Martinus Nijhoff Publishers, 1996), pp. 51ff and pp. 183ff).

9 UN Doc. A/CONF.164/L.11/Rev.1, Art. 1(1) submitted by Argentina, Canada, Chile, Iceland and New Zealand (reprinted in Lévy and Schram, note 38 above at pp. $163 f f$ ).

40 See UN Doc. A/CONF.164/L.14, Section IV(1), submitted by Chile, Colombia, Ecuador and Peru, which inter alia envisages that regional agreements would list its (straddling) stocks in annexes. Sec also the definitions in UN Doc. A/CONF.164/L.44, Art. 1(xx) and (xxiv), submitted by Ecuador. Both documents are reprinted in Lévy and Schram, note 38 above at pp. $187 f f$ and pp. $503 f f$.

41 See UN Docs A/CONF.164/L.18, A/CONF.164/L.32, A/CONF.164/L.32/Add.1, A/ CONF.164/L.38, A/CONF.164/L.46, A/CONF.164/L.47 (and Corr.1). All documents are reprinted in Lévy and Schram, note 38 above at pp. $215 f f$, pp. $257 f f$, pp. $477 f f$, pp. $663 f f$ and pp. $725 f f$.

42 Cf. F. Orrego Vicuña, The Changing International Law of High Seas Fisheries (Cambridge, Cambridge University Press, 1999), p. 140.

43 See Arts 66, 67, 68 and 77(4) of the LOS Convention.

44 See Arts 64, 65 and 120 of and Annex I to the LOS Convention.

45 Wellington Workshop, note 12 above at pp. 2-3. New Zealand maintains its position that the stock in question is not a straddling stock, but should in any case be managed as a single stock. 
but does not need to migrate between them. However, stocks that do migrate must also be straddling stocks. The duty to co-operate under Article 63(2) seeks to deal with transboundary effects and these clearly arise with stocks that migrate. But Article 63(2) thus also covers stocks that do not migrate but simply occur in both zones. ${ }^{46}$ Normal dispersal processes ensure more or less random (passive) movement by individuals of the stock through part or the entirety of the stock's range of distribution, for instance in search of better feeding grounds. Where such a process takes place, fishing also has transboundary effects.

The disagreement between Australia and New Zealand on the characterisation of orange roughy on the South Tasman Rise therefore seems to concern the question whether there is any migration or dispersal and, if so, if this would be significant enough to justify management of separate stocks. In the specific case of the orange roughy stock on the South Tasman Rise, inter alia due to the fact that high concentrations are not so far apart, there is at least a strong risk of transboundary effects and an ensuing presumption that multilateral co-operation is required. The precautionary approach supports and reinforces the need both to presume such risks and to co-operate. This can subsequently be confirmed or refuted by dedicated marine scientific research. In the interim period, the precautionary approach also has consequences for the appropriate form of management. In general, where it is uncertain if there are one or two stocks (or two stock components), the precautionary approach indicates that the fishery should in principle be dealt with as if it consisted of two stocks (or components). ${ }^{47}$ Until such time as research resolves this uncertainty, however, multilateral management is essential in order to minimise transboundary effects should there in fact be only one stock. The reason why Australia and New Zealand have nevertheless decided to manage the stock as a single discrete stock could be strongly related to the fact that directed fishing effort and catches of

46 Cf. R.R. Churchill and A.V. Lowe, The Law of the Sea (Manchester, Manchester University Press, 3rd ed., 1999), p. 305, who observe that "straddling stocks are stocks of fish that migrate between, or occur in both, the EEZ of one or more States and the high seas". However, E. Hey, The Regime for the Exploitation of Transboundary Marine Fisheries Resources (Dordrecht, Martinus Nijhoff Publishers, 1989), pp. 82-83, only refers to the migratory character. Migration is understood to be cyclical (active) movement by more or less the entire (adult) population from one particular place to another.

$47 \mathrm{Cf}$. almost the exact wording used by Dr Maguire in relation to the discussions in NEAFC on Sebastes mentella in the Irminger Sea (1998 NEAFC Annual Report, note 3 above at p. 4, paras 11-12). In 1999, ICES (International Council for the Exploration of the Sea) advised that there are indications of two stock components that are genetically distinct (one occurring below 500 metres and one above) and that management measures are required to ensure that the individual stock components are not overexploited. Much to Iceland's disappointment, NEAFC ultimately decided not to differentiate management, essentially for practical reasons (Report of the 18th Annual Meeting (1999) of NEAFC, pp. 5-7 and 57). ICES seems to have repeated its advice in 2000 (for 2001). Not differentiating management may bring the risk that one stock (or one component) collapscs. In addition, the conscquential loss of genetic diversity may eventually lead to decreased fitness of the species (or stock). See also Art. 6(6) of the 1995 Fish Stocks Agreement, which concerns the application of the precautionary approach to new and exploratory fisheries. 
orange roughy in the AFZ section of the South Tasman Rise are relatively low. ${ }^{48}$

Despite their disagreements, Australia and New Zealand continue to cooperate in scientific research on orange roughy within the framework of the 2000 STR Arrangement. ${ }^{49}$ Paragraph 12 indicates that the primary research objective has now become the assessment of stock abundance and sustainable yield. Measuring the size of orange roughy populations is a difficult undertaking due to their deep-sea habitats, their wide distribution and their alternating dispersed and aggregating behaviour. This research objective would probably be the main one for most capture fisheries. At the same time, the fact that paragraph 12(b) articulates the need for further research on the categorisation of the stock(s) shows that the two states have not put all differences aside in order to focus on the sustainability of the fishery. The significance of the issue can also be deduced from the eighth preambular paragraph of the 2000 STR Arrangement. Here the parties acknowledge:

"that the methodologies developed through a scientific research program for orange roughy on the South Tasman Rise, including mutually acceptable criteria for determining whether or not a stock is a straddling stock, will assist in broader assessments of orange roughy stock characteristics in the Tasman Sea region." 50

This paragraph should be read in conjunction with paragraph 36 , which contains a non-prejudicial clause with respect to future arrangements or agreements on "Tasman Sea fisheries generally or orange roughy on the high seas area of the South Tasman Rise". Both provisions indicate that agreement on the issue of categorisation may have consequences that extend beyond the management of orange roughy on the South Tasman Rise. Apart from stocks of orange roughy that are newly discovered, an example that springs to mind would be the stock on the Challenger Plateau (as discussed below). ${ }^{51}$ Furthermore, the reference to "Tasman Sea fisheries generally" aptly illustrates the much wider context. In light of these broader implications it is understandable why Australia accorded so much importance to the categorisation issue despite the fact that only

48 The risk of local depletion, should there in fact be two stocks and not one, is thus relatively small. The 500-tonne trigger mentioned in note 36 above indicates that Australia could respond quickly if this risk increases.

49 See paras 12-16. In contrast with the 1998 STR Arrangement, these paragraphs do not provide insight into how the research will be carried out. The research seems primarily directed at orange roughy even though the preamble (para. 6) refers to "other species" and paras 15, 17, 18 and 25 refer to "associated species". Paras 2 and 11 use "all species" because, more generally, high seas fishing should only take place with prior authorisation.

50 This basically repeats para. 7 of the 1998 STR Arrangement. Para. 23 of the 1998 STR Arrangement provided that if "the preponderance of the evidence indicates that the orange roughy stock on the South Tasman Rise is a straddling stock ... the Parties will establish a consistent approach towards conservation, management and allocation for all straddling fish stocks in the Tasman Sca region, consistent with" the 1995 Fish Stocks Agreement.

51 Other examples could be the stock(s) on the Lord Howe Rise. 
relatively small catches had so far been taken in the AFZ section of the South Tasman Rise.

It should finally be noted that the South Tasman Rise would probably fall within the outer limits of the legal continental shelves which Australia could claim on the basis of Article 76 of the LOS Convention. New Zealand could probably make a similar claim with regard to the Challenger Plateau. A coastal state's sovereign rights over sedentary species pursuant to Article 77 of the LOS Convention entitles it to some extent of regulatory compctence over fisheries for non-sedentary species if necessary to avoid an impact on sedentary species. Rather than an issue of transboundary effects, this is a case of conflict between coastal and flag states in the same spatial area. Claims to jurisdiction under Article 77 would therefore further complicate management of orange roughy.

\section{Allocation}

Although it is not attempted to address thoroughly the issue of "allocation of fishing opportunities" 52 (hereinafter "allocation"), some comments can be made on its relationship with the aspect of categorisation. Agreement on the categorisation of a stock only determines whether co-operation is actually needed and, if so, what requirements such co-operation must meet. For example, if it is agreed that a fish stock is either straddling or highly migratory, co-operation would in particular be governed by the 1995 Fish Stocks Agreement and commonly involve both flag and coastal states. ${ }^{53}$ Accordingly, the duty to cooperate is geared towards the objective of compatibility between conservation and management measures established for the high seas and those adopted for EEZs. ${ }^{54}$ The other relevant alternative, for this article, is when it concerns a discrete high seas stock. The ensuing duty to co-operate would in that case primarily be governed by general international law, including the LOS Convention, and involve exclusively states in their capacities as flag states. This latter situation will also be the subject of discussion in the section on the southern Indian Ocean below.

"Allocation of fishing opportunities" is a broader term than "allocation of national quotas" to which the discussion in this article was so far limited. It is intended to comprise all the various management measures intended to ensure that catches do not exceed a certain level, whether or not this level is a TAC. Such measures include quotas, limited fishing effort (including closed areas/seasons) or the closing of the fishing season once the TAC has been reached (see also Art. 10(b) of the 1995 Fish Stocks Agreement, which uses "participatory rights").

53 Provided of course that the 1995 Fish Stocks Agreement is in force and also applicable between states involved. It is nevertheless not ruled out that only coastal states would be participants, for example in case of high seas enclaves (sec Part IX of the LOS Convention and Arts 15 and 16 of the 1995 Fish Stocks Agreement). See also Orrego Vicuña, note 42 above at p. 208. At ibid., p. 194 he observes that the use of the term "enclaves" was avoided as it might have reinforced coastal state jurisdiction.

54 Art. 7(2). The phrase "areas under national jurisdiction" in this and other provisions of the 1995 Fish Stocks Agreement is intended to mean the EEZ (cf. E.J. Molenaar, "The Concept of 'Rcal Interest' and Other Aspects of Co-operation Through Regional Fisheries Management Mechanisms", (2000) 15 International Journal of Marine and Coastal Law 478). 
More complex is the relationship between categorisation on the one hand, and allocation and access to the resource on the other hand. On account of its sovereignty or sovereign rights over the living marine resources in its maritime zones, the coastal state has practically exclusive powers over regulating access to these resources. ${ }^{55}$ This also applies to straddling and highly migratory fish stocks within its maritime zones. ${ }^{56}$ However, due to their transboundary character, it is essential that the allocation is jointly agreed upon by all the states involved. The coastal state's wide margin of discretion in regulating access to its maritime zones cannot be used in disregard of its duties to co-operate with respect to transboundary stocks. A coastal state therefore has to respect an allocation that is agreed upon at the (sub)regional or global level, provided the allocation and the means by which it has been agreed are consistent with the relevant rules of international law. ${ }^{57}$

Apart from stocks whose spatial distributions are entirely within the maritime zones of a single state, categorisation always identifies more than one state with rights over these stocks. The ensuing need for allocation is hampered by the lack of rules of international law that specifically govern it. The LOS Convention effectively does no more than confirm the respective rights of states in their different capacities as coastal states or flag states. ${ }^{58}$ The 1995 Fish Stocks Agreement merely lists criteria that are relevant for the allocation issue without prioritising or otherwise suggesting how they are to be applied. It concerns: (1) subparagraphs (d) and (e) of Article 7(2), which are part of the exhaustive list of criteria that have to be taken into account to ensure compatibility; (2) the non-exhaustive list of factors in Article 11 that members or participants in regional fishories management mechanisms (RFMMs) ${ }^{59}$ shall take into account in determining the nature and extent of participatory rights for new

55 Pursuant to Art. 62(2) and (3) of the LOS Convention, coastal states have an obligation to give access to the surplus in the TAC of the EEZ, whereas other states have a right to participate in the exploitation of this surplus pursuant to Arts 69 and 70 of the LOS Convention. The wording of these provisions, in particular the ground of "other national interests" in Art. 62(3), and the limitation on compulsory dispute settlement procedures entailing binding decisions in Art. 297(3), makes it clear that flag states are virtually powerless against the coastal state's wide margin of discretion. State practice after the adoption of the LOS Convention confirmed this.

56 The United States initially took the view that these wide coastal state powers did not extend to highly migratory species.

57 See Art. 1(1)(b) of the 1995 Fish Stocks Agreement. On the pivotal condition of "consistency", see note 114 below and accompanying text (even though that discussion specifically relates to the consistency with international law of an RFMM as such, and not just the measures adopted by it).

58 Art. 62(2) of the LOS Convention spccifics that coastal states, in giving other states access to its surplus in the TAC of its EEZ, shall have "particular regard" to land-locked and geographically disadvantaged states, and especially those that are developing states. Nevertheless, these other states "merely" have a right to participate in exploitation and not a right to the resources as such. Sec also note 55 above.

59 The acronym RFMM is used as an overarching term inspired by the distinction between organisations and arrangements in the 1995 Fish Stocks Agreement. 
members or participants; and (3) Article 24(a) which concerns the special requirements of developing states. ${ }^{60}$

Notably absent in these two treaties is a fundamental norm which acts as a benchmark for allocation, let alone a set of allocation rules that is generally applicable while at the same time sufficiently precise to produce consistent and predictable outcomes. In light of the similarities with allocation, a comparison could here be made with maritime boundary delimitation. The fundamental norm of maritime delimitation law, as formulated by the International Court of Justice in the Libya/Malta Continental Shelf case is that "the delimitation is to be effected in accordance with equitable principles and taking account of all relevant circumstances, so as to arrive at an equitable result". ${ }^{1}$

It is less clear-cut if international law contains a similar fundamental norm with respect to the allocation of participatory rights in the exploitation of transboundary living marine resources. The norm "to ensure the long-term conservation and sustainable use"62 of transboundary stocks would perhaps better be regarded as a more superior or overarching norm, which does not specifically govern the outcome of the balancing of the different rights and interests of states. However, in the 1974 Fisheries Jurisdiction (Merits) cases, ${ }^{63}$ the ICJ explicitly held that the states involved were "under mutual obligations to undertake negotiations in good faith for the equitable solution of their differences concerning their respective fishery rights". ${ }^{64}$ Recognition of the significance of equity in multilateral fisheries management in general, and of allocation in particular, is also apparent in many other paragraphs of the Judgment. ${ }^{65}$ Moreover, in the review of allocation practices that is currently

See also the various factors that a coastal state has to take into account in setting the TAC for its EEZ and for giving access to other states to the surplus in this TAC (Arts 61 and 62 of the LOS Convention).

61 Case Concerning the Continental Shelf (Libyan Arab Jamahiriva/Malta), Judgment of 3 June 1985, [1985] ICJ Rep 13 at 57, para. 79, under A(1). It should be noted, however, that this norm is inter alia deducted from case law and varies from Arts 15,74(1) and 83(1) of the LOS Convention, which specifically concern the territorial sea, EEZ and continental shelf respectively.

62 This clause is taken from Art. 2 of the 1995 Fish Stocks $A$ greement. Overarching objectives used in the 1995 FAO Code of Conduct (Code of Conduct for Responsible Fisheries, Rome, 31 October 1995, www.fao.org/WAICENT/FAOINFO/FISHERY/fishery.htm) include "responsible fisheries" (Art. 2(c)), "effective conservation and management" (section 6.1), "sustainable utilisation" (sections 6.3 and 7.2.1) or "long-term conservation and sustainable use" (section 7.1.1).

63 Fisheries Jurisdiction Case (United Kingdom v Iceland). Merits, Judgment of 25 July 1974, [1974] ICJ Rcp 3; Fisheries Jurisdiction Case (Federal Republic of Germany v Iceland), Merits, Judgment of 25 July 1974, [1974] ICJ Rep 175.

64 [1974] ICJ Rep 34, para. 79, under (3) and p. 205, para. 77, under (3).

65 E.g. equitable solution (p. 30 , paras 69 and 70 ; p. 32, para. 73 ; p. 33 , para. 78 ), equitable exploitation (p. 31, para. 72; pp. 34.35, para. 79, under (4)(c), (d) and (e)) and equitable allocation (p. 31, para. 73; p. 33, para. 78). Sce also A.G. Oude Elferink. "The Impact of Article $7(2)$ of the Fish Stocks Agreement on the Formulation of Conscrvation and Management Measures for Straddling and Highly Migratory Fish Stocks", FAO Legal Papers Online No. 4, August 1999, www.fao.org/Legal/pub-e.htm, who inter alia examines the potential role of equity 
carried out within the International Commission for the Conservation of Atlantic Tunas (ICCAT), support seems to exist for a fundamental norm of "ensuring equitable fishing opportunities for all members". ${ }^{66}$ Together with the Judgment of the ICJ, these are strong indications that, while the role of equity in allocation may not be explicitly mentioned in the LOS Convention or the 1995 Fish Stocks Agreement, support for such a role nevertheless exists under general international law. ${ }^{67}$

Nor has maritime delimitation law, apart from the fundamental norm just cited, been able to develop detailed rules that facilitate consistency and predictability of outcomes. Various equitable principles and relevant circumstances have been applied in relevant case law, but no attempt has been made to draw up an exhaustive list of these. ${ }^{68}$ As is evident from the relevant provisions in the LOS Convention and the 1995 Fish Stocks Agreement cited above, the same is largely true for allocation. More precise allocation practices have nevertheless been devcloped within RFMMs, with historical catches often playing a prominent role. But, even there, it is extremely difficult to ascertain which factors or (legal) rules have played a role in the allocation and what their relative importance has been. States involved in a maritime delimitation dispute are not primarily interested in agreeing on a common understanding of the applicable law. Their main objective is to agree on a maritime boundary. Similarly, states are primarily interested in agreeing on an allocation and not on the applicable law.$^{69}$ This also allows them to take different positions in different fora if that would be more conducive to their interests. Of course, the uniqueness of each case also gives states ample room to manocuvre while denying that their positions are contradictory.

Cont.

and the need to arrive at an equitable solution in balancing the various factors in Art. 7(2) of the 1995 Fish Stocks Agreement, which states have to take into account in light of the objective of compatibility.

66 Para. 6.87 of the Report of the 1st Mecting of the Working Group on Allocation Criteria (Annex 6 to the 1999 ICCAT Report, available at www.iccat.es). The EC and the United States agreed that this objective should appear in the chapeau of an agreed document on allocation criteria.

67 Reviews of allocation practices within NEAFC and NAFO (Northwest Atlantic Fisheries Organization) did not address the need for a fundamental norm. It is noteworthy that para. 71 of the Sydney Draft IPOA on IUU Fishing, note 7 above, stipulated that RFMOs "should address the issue of access to the resource in a timely, realistic and equitable manner in order to foster co-operation and enhance sustainability in the fishery". In the October 2000 Draft IPOA on IUU Fishing, note 7 above, the words "in a timely, realistic and equitable manner" have been left out, although the sentence now ends with "in accordance with international law".

68 Cf. A.G. Oude Elferink. The Law of Maritime Boundary Delimitation: A Case Study of the Russian Federation (The Hague, Boston and London, Martinus Nijhoff Publishers, 1994), at pp. 113130 , in particular p. 126. Geographical factors are the most importance "relevant circumstances", especially islands and the proportionality test in relation to lengths of coasts. Often, the equidistance line plays a role as well, in particular for opposite coasts and provided it leads to an equitable solution.

69 See the comments by the United States in the 1999 ICCAT Report, note 66 above at para. 6.13. 
But, while the outcome of a maritime delimitation is intended to be final, allocations have to be set regularly, often each year. The states involved therefore have a clear incentive to strive for a higher measure of consistency and predictability, if only to shorten difficult negotiations. Considerable departures from existing allocations, whether or not as part of a more permanent practice, stand little chance of being acceptable. Changes are thus expected to be gradual. At the same time, allocation practices cannot be too rigid as the relative weight of individual factors may change over time.

One option for some measure of consistency and predictability, which may also be relevant for the situation in the South Tasman Rise, is offered by the concept of "zonal attachment". This concept has been included in Article 7(2)(d) of the 1995 Fish Stocks Agreement where it notes that "the extent to which the stocks occur in areas under national jurisdiction" shall be taken into account in determining compatible conservation and management measures. ${ }^{70}$ In the context of allocation, the concept of zonal attachment essentiali; seeks to resolve the problem of the non-sedentary character of fish by determining the spatial distribution of biomass. This spatial distribution could then act as .. allocation criterion. ${ }^{71}$ The fact that Article 11 of the Agreement does not contain a similar clause or criterion in relation to new entrants to RFMMs could indirm. that all relevant coastal states are presumed to be already included in existing RFMMs. In reality this is not always the case. ${ }^{72}$ At any rate, the list in Article 11 is non-exhaustive and coastal states wishing to participate in RFMMs are expected to invoke the concept. In the allocation discussions in the North-East Atlantic Fisheries Commission (NEAFC), the Northwest Atlantic Fisheries Organization (NAFO) and ICCAT the concept of zonal attachment is frequently referred to ${ }^{73}$ and in several instances it seems to have been effectively applied. ${ }^{74}$

The words omitted from this citation ("and are fished") point to the relevance of catch histories. E.g. the spatial distribution may be 70 per cent within the maritime zones of coastal states and 30 per cent on the high seas. Using this as an allocation criterion does not automatically mean that 70 per cent of the allocation is given to the coastal state(s). Also, it is not excluded that the coastal state(s) would be entitled to part of the 30 per cent on the basis of other criteria, for instance their catch history.

E.g. many relevant coastal states, including Denmark (in relation to the Faroe Islands), Iceland, Malta, Norway and Turkey, are currently non-members of ICCAT.

Sec the Report of the NEAFC Working Group on Mackerel and Blue Whiting, March 1998, p. 10, para. 49; NAFO GC Doc. 99/4, Section 5 and Annex 8 (Question A-2); the 1999 ICCAT Report, note 66 above at paras $6.8,6.12,6.44,6.47,6.50,6.52,6.55$ and $6.75-6.78$; and the Report of the Second Meeting of the ICCAT Working Group on Allocation Criteria (2000, at the time of writing not yet officially adopted), paras 5.72-5.74. One of the attempts by Iceland, Norway and the Russian Federation to agree on allocation in the Barents Sea Loophole was also based on zonal attachment (cf. R.R. Churchill, "The Barents Sea Loophole Agreement: A 'Coastal State' Solution to a Straddling Stock Problem”, (1999) 14 International Journal of Marine and Coastal Law $467-483$ at 470 ).

E.g. the allocation for shrimp in NAFO Division 3L (five-sixths allocated to Canada: see NAFO FC Doc. 99/15, paras 4.494 .58 and Annex 8). In view of the relatively static nature of shrimp, zonal attachment would be particularly suitable. 
While the concept may be accepted as a matter or principle in all these fora, the hurdles that should be overcome before it can be given effective meaning are considerable, in particular for highly migratory fish stocks. ${ }^{75}$

The concept of zonal attachment underscores the potential contribution of science in providing more consistency and predictability to allocation practices. The expectations for its role should nevertheless be modest. After all, the many allocation criteria mentioned in the 1995 Fish Stocks Agreement lack hierarchy or an indication of their relative weight. All states would be able legitimately to invoke at least one of these criteria. It should also be acknowledged that extralegal elements play an important role when allocations are being negotiated. At best, zonal attachment could therefore be the main allocation criterion among a variety of other, less important, criteria such as catch history.

\section{General Approach Towards Third Countries}

The experience with the vessels registered in South Africa and Belize in June 1999 proved that the remoteness of the South Tasman Rise was not seen as an impediment. The presence of the foreign vessels also came as a surprise because the exact location of the profitable fishing grounds had until then been confidential. ${ }^{76}$ Their departure clearly did not resolve the problem. Not long thereafter the South African Government apparently made a request to participate in the fishery. Despite the fact that the 2000 STR Arrangement provides for new participants in the fishery (see below), nothing explicitly indicates the involvement of South Africa. ${ }^{77}$

Awareness of the potential impact of fishing by "others" has led to the incorporation of a relatively large number of paragraphs in the 2000 STR Arrangement that explicitly deal with third countries. The 1998 STR Arrangement only included a single provision, paragraph 17 , that dealt with landings at ports of Australia and New Zealand. This provision has basically been retained in paragraph 25 of the 2000 STR Arrangement and will be

75 What weight should for instance be given to the location of spawning and nursing grounds, where the stock spends most of its life-cycle or where it is caught (see in this regard Arts 66 and 67 of the LOS Convention, which specifically address "homing behaviour")? Especially problematic are the considerable annual changes in the distribution of biomass in relation to highly migratory fish stocks. This explains the support by Canada and the EC of the concept in NAFO but not in ICCAT. South Africa suggested that the concept would not have to be quantificd in order to be applied. The United States and Venezuela agrecd (sec the 2000 ICCAT Report, note 73 above at para. 5.74).

76 In fact, at the time the Australian media devoted considerable attention to identifying those responsible for the disclosure of the location. It is also possible that data transmitted as part of a satellite-based vessel monitoring system (VMS) were intercepted. Para. 19 of the 2000 STR Arrangement addresses the confidentiality of information "regardless of its form".

77 This raises the question whether Australia and New Zealand have acted consistently with Art. 63(2) of the LOS Convention and Art. 8(5) of the 1995 Fish Stocks Agrecment (which is not in force). See the section entitled "Classification of the 2000 STR Arrangement and Other Alternatives to Flag State Jurisdiction" below. 
discussed in section below on port state jurisdiction. Noteworthy is that all relevant paragraphs of the 2000 STR Arrangement consistently use "third countries" and not "third States". ${ }^{78}$ Conversely, paragraph 17 of the 1998 STR Arrangement uses "State". ${ }^{79}$ Unlike "States", the term "countries" is not a generally accepted legal term under international law. While "countries" may be legal persons in the domestic sphere, in the ambit of international law it connotes nothing more than geographical or administrative units of states. One reason for choosing "countries" could therefore be that it is flexible enough to encompass "entities" and "fishing entities" as used in Article 1(2)(b)(i) and (3) of the 1995 Fish Stocks Agreement. Taiwan, widely regarded as really the only existing fishing entity in the sense of Article 1(3) of the 1995 Agreement, would thus be covered by the term "countries". ${ }^{80}$ The choice for this term may also be perceived as evidence of the flexible attitude of Australia and New Zealand in ongoing consultations in several fora on the participatory status of Taiwan. ${ }^{81}$ In the following discussion, "countries" is used to be consistent with the Arrangement even where it would be more appropriate to use "States" from an international legal perspective.

Paragraphs 26-32 of the 2000 STR Arrangement address the issue of third countries in such a comprehensive way that it recalls current practice within many RFMMs. ${ }^{82}$ The parties co-operate in surveillance of the high seas area of the South Tasman Rise. Upon sightings of vessels of third countries that are engaged in fishing, and thereby undermine or threaten to undermine the effectiveness of the Arrangement, the parties will approach that country to seek its co-operation in the conservation and management of the stock. ${ }^{83}$ Pursuant to paragraph 28 , co-operation is also sought of other countries than those where the vessel is registered. This is inter alia discussed below in the section on the

79 Sec paras 26-28 and 30-31

The relevant wording in para. 17 is: "the vessels of any State which is not a signatory to this Arrangement". Para. 16 uses "country" to refer to either Australia or New Zcaland.

80 The phrase "the flag State of a vessel from a third country" in para. 27 of the 2000 STR Arrangement indicates that responsibility under international law may not be with the country. In most cascs, including the special case of Taiwan, country and flag state will be one and the same. Regional economic integration organisations such as the EC would not be covered by the term "countries". The 2000 STR Arrangement could of course be amended but this is probably not necessary in light of the small size and therefore importance of the fishery.

81 E.g. the Commission on the Conscrvation of Southern Bluefin Tuna; sce note 24 above. See also Annex I ("Fishing Entities") to the Convention on the Conservation and Management of Highly Migratory Fish Stocks in the Western and Central Pacific Ocean (Honolulu, 5 September 2000 , not in force).

82 E.g. the Commission on the Conservation of Antarctic Marine Living Resources (CCAMLR) and NAFO.

83 See note 80 above for the potential difference between the country and the flag statc. Morcover, although the words "that by fishing ... undermines or threatens to undermine the effectiveness" can be interpreted in several ways, it is presumed that the very act of fishing "undermines or threatens to undermine" (see also para. 25, which simply links the prohibition of landing to catch "taken"). It is noteworthy that para. 27 uses "fishing" and not the broader term "fishing activities", which is the object of surveillance under para. 26. 
classification of the 2000 STR Arrangement and other alternatives to flag state jurisdiction. Furthermore, Australia and New Zealand commit themselves, pursuant to paragraph 30 , to co-operating with:

"third countries which have a real interest in the conservation and management of orange roughy on the South Tasman Rise with a view to securing the application by them of the conservation and management measures of this Arrangement."

Australia and New Zealand do not make this commitment towards all third countries, but only towards those "which have a real interest" etc. This implies that third countries without a real interest are not co-operated with but that their co-operation is merely sought in accordance with paragraph 27 . This distinction is also apparent in the words "securing the application by them" which, when compared to paragraph 27 , entail a much more direct involvement of third countries in conservation and management. The link between having a real interest and a more direct involvement also follows from paragraph 31 , which allows third countries with a real interest to make a request to become a party to the 2000 STR Arrangement. Paragraph 27, on the other hand, is primarily intended to make third countries aware of, or to reaffirm, the existence of the Arrangement. For this very reason, the Arrangement has also been lodged with the Food and Agriculture Organization (FAO) ${ }^{84}$ Both approaches are aimed at ensuring that co-operative countries act like South Africa and Belize did in June $1999 .{ }^{85}$ Whether all countries would be willing to do that entirely pro deo is of course a different issue. At any rate, some third countries may (subsequently) wish to become more directly and genuinely involved in conservation and management and make a request to become a party.

Before discussing how such a request may be dealt with, it is necessary to elaborate briefly on the "real interest" qualification. This concept has been laid down in Article 8(3) of the 1995 Fish Stocks Agreement as a general condition that states must meet in order to become members of RFMMs, or participate in them. As Article 8(4) of the same Agreement provides that only those states that participate in RFMMs shall have access to the fisheries resources regulated by those RFMMs, being able to participate and thus meeting the condition of real interest has obvious significance. As analysed in detail elsewhere, ${ }^{86}$ the concept of real interest is not defined in the 1995 Fish Stocks Agreement nor has state practice so far led to a widely accepted and uniform definition. The way in which the concept has been formulated in paragraph 30 of the 2000 STR Arrangement,

84

85

Their co-operative attitude may have been based on a recognition that, in the specific circumstances of the case, their vessels' activities were threatening the sustainable management of the stock (cf. Art. 117 of the LOS Convention) or on the simple fact that they were unaware of the existence of the 1998 STR Arrangement.

86

See Molenaar, note 54 above. 
namely, "in the conservation and management of orange roughy on the South Tasman Rise", deviates somewhat from the words "in the fisheries concerned" in Article 8(3) of the 1995 Fish Stocks Agreement. Whether this divergence is intentional and, if so, what implications it would have, is hard to say.

Irrespective of the meaning of the concept of real interest, it is in principle only applicable in the context of the 1995 Fish Stocks Agreement. Under general international law, in this case laid down in Article 116 of the LOS Convention, all states have a conditional right to fish on the high seas. Having a real interest is not among these conditions and could thus only be applied once the 1995 Fish Stocks Agreement enters into force and even then only between parties. The same applies to other aspects of the Agreement that do not also have a basis in the LOS Convention or general international law. While the first preambular paragraph of the 2000 STR Arrangement mentions the parties' shared intention of ratifying the 1995 Fish Stocks Agreement, so far only Australia has ratified the latter. ${ }^{87}$ Their effort to make the 2000 STR Arrangement consistent with the 1995 Fish Stocks Agreement is commendable but the applicability of certain of the Arrangement's elements obviously still depends first of all on the readiness of other states to become parties to the 1995 Fish Stocks Agreement.

Paragraph 31 of the 2000 STR Arrangement provides that the parties "will jointly consider in terms of Article 11 of the 1995 Agreement" a request to become party to the Arrangement. Furthermore, paragraph 32 governs certain procedural aspects when a new party is included in the Arrangement, in particular that the appropriate instrument will "[set] out the participatory rights of the new Party". Nothing in the careful wording of these paragraphs, in particular the cited phrases, suggests that a request will be rejected, provided of course that the third country has a real interest. In light of the above discussion, it is certainly understandable that this term remains undefined. Moreover, the words "participatory rights" should not necessarily cause suspicion either as they have been drawn directly from Article 11 of the 1995 Fish Stocks Agreement. Paragraphs $30-32$ of the 2000 STR Arrangement would therefore not exclude participation by a new party which is not interested in an allocation, but which is mainly concerned with conservation and management per se. On the other hand, it is certainly not evident that new entrants can simply be denied an allocation if they would be interested. A particularly relevant factor in relation to allocations might be that the fishery is currently relatively small. Moreover, the remoteness of the area might impact on the economic viability of fishing and the potential surveillance obligations for new entrants.

Above all, the co-operative efforts of Australia and New Zealand in the conservation and management of orange roughy on the South Tasman Rise should be appreciated in light of their obligations under the LOS Convention 
and general international law as well as for their consistency with the 1995 Fish Stocks Agreement, in particular with the latter's Article 8(2) which specifically concerns new fisheries. The fact that the 2000 STR Arrangement has a procedure for absorbing new entrants is a valuable improvement in comparison to the 1998 Arrangement, which contained nothing of the sort. Progress has furthermore been achieved by giving the 2000 Arrangement wider publicity in comparison to its predecessor, which is also relevant for opposability to other states. Nevertheless, the way in which Australia and New Zealand will apply the requirement of real interest and the extent to which the participatory rights offered to new entrants are equitable, will be crucial for assessing the "openness" of the 2000 STR Arrangement. The diligence with which these tasks are undertaken will ultimately determine if the various measures against non-parties to the Arrangement are consistent with current international law. ${ }^{88}$ The first litmus test may not be too far off, as both Namibia and South Africa have apparently already made a request to become involved in the fishery. ${ }^{89}$ Australia and New Zealand have invited the two applicants for a meeting some time at the end of 2000 .

\section{Port State Jurisdiction}

On account of its territorial sovereignty, general international law acknowledges that a state has wide discretion in exercising jurisdiction over its ports. Port states in principle have a right to deny foreign (fishing) vessels access to ports, subject to such general exceptions as distress and force majeure. Implicit in this broad competence is the less intrusive right of specifying conditions for entry into port. As a whole, these powers make port state jurisdiction a powerful tool. It has proven its effectiveness as a remedy against vessels flying the flag of states that are unwilling or incapable of exercising effective jurisdiction and control in the sphere of vessel safety and the prevention of pollution and, more recently, in marine capture fisheries.

88 On the pivotal condition of "consistency", see note 114 below and the accompanying text (even though that discussion specifically relates to the consistency with international law of an RFMM as such, and not just the measures adopted by it).

89 Whether these requests were made under para. 31 of the 2000 STR Arrangement is unclear. In a letter of 11 November 1999 to W. Truss (Australian Minister of Agriculture, Fisheries and Forestry), A. Iyambo (Namibian Minister of Fisheries and Marine Resources) already expressed a certain interest in the South Tasman Rise fishery. In a letter of 28 January 2000 , the Australian Minister replies that New Zealand is "the only other country with a demonstrated and legitimate real interest in the area". In a further letter of 30 June 2000 , the Namibian Ministcr reaffirms that Namibian vessels intend to fish in the Southern Ocean (presumably including the STR) and the south-west Indian Ocean, and that Namibia has a real interest.

An interesting question is whether South Africa can claim to be a "State fishing" for orange roughly on the South Tasman Rise and whether this fishing activity amounts to a historical catch. Australian officials doubt this, pointing out that (1) South Africa was unaware of the vessels' presence and (2) disapproved of their behaviour once it found out. A related question is the extent to which this would be necessary in relation to the concept of real interest. 
The 2000 STR Arrangement deals with port state jurisdiction in paragraph $25,{ }^{90}$ which stipulates:

"Each Party will prohibit vessels not authorised under this Arrangement to fish in the high seas area of the South Tasman Rise from landing in its ports orange roughy and associated species taken in the high seas area of the South Tasman Rise."

This provision essentially repeats paragraph 17 of the 1998 STR Arrangement, except for two important innovations. First, even vessels flagged in countries that are parties to the 2000 STR Arrangement would not be able to land relevant catch if they have not been authorised to fish in the high seas area of the South Tasman Rise. This adds to the non-discriminatory nature of the prohibition. ${ }^{91}$ Secondly, the landing prohibition now also applies to "associated species".

The prohibition in paragraph 25 governs prior behaviour that has taken place beyond the maritime zones where partics have sovereignty or sovereign rights. A narrow view would argue that without jurisdiction based on either the territorial principle (territorial sea and archipelagic waters) or the quasiterritorial principle (EEZ), the LOS Convention would offer no basis for this type of port state jurisdiction as it would be inconsistent with its Articles 63(2), 89 and 116-119. A broader but also more controversial view would emphasise that the transboundary effects caused by straddling stocks constitute a sufficiently close connection with the port (coastal) state and therefore permit jurisdiction based on the objective quasi-territorial principle. ${ }^{92}$ But perhaps it is not even necessary to rely on this broader view in light of Article 23 of the 1995 Fish Stocks Agreement, which deals with "Measures taken by a port state". Paragraph (3) provides:

\begin{abstract}
"States may adopt regulations empowering the relevant national authorities to prohibit landings and transhipments where it has been established that the catch has been taken in a manner which undermines the effectiveness of subregional, regional or global conservation and management measures on the high seas."
\end{abstract}

This port state right to prohibit landings is essentially similar to that in paragraph 25 of the 2000 STR Arrangement. The differences that exist between the two are not problematic. ${ }^{93}$ As the 1995 Fish Stocks Agreement has not yet

90 Para. 24 merely recognises that parties may have different port policies.

91 See note 32 above and the accompanying text.

92 For a discussion on jurisdiction, sce E.J. Molenaar, Coastal State Jurisdiction over Vessel-Source Pollution (The Hague, Boston and London, Kluwer Law International, 1998), pp. 7880.

93 While para. 25 does not contain the common phrase "undermines the effectiveness", it can be argued that the mere act of fishing without prior authorisation leads to this result. This is also implicit in para. 27 of the 2000 STR Arrangement (see note 83 above). Moreover, while Art. 23(3) of the 1995 Agreement is an optional competence, the parties to the 2000 STR Arrangement 
entered into force, however, Article 23(3) cannot be used as a jurisdictional basis exclusively on its own terms. This brings us to the heart of the controversy on port state jurisdiction. This controversy is inter alia reflected in paragraph (4) to Article 23, which reads:

"Nothing in this article affects the exercise by States of their sovereignty over ports in their territory in accordance with international law."

This non-prejudicial clause indicates that some delegations that negotiated the 1995 Fish Stocks Agreement regarded the various port state measures incorporated in Article 23 as innovations that, as a consequence, can only be exercised inter se. Other delegations took the view that these powers confirmed what port states would already be entitled to under general international law or even that port states have wider powers. Support for this latter view exists in the practice of several RFMMs that prescribe port state powers similar to those in Article 23 of the 1995 Fish Stocks Agreement, without taking account of the fact that non-parties to the RFMMs are parties to the 1995 Agreement. ${ }^{94}$ Moreover, it will not be difficult to find state practice that goes even beyond that. The view of the present author, however, is that each competence, no matter how broad, must necessarily have its limits. General international law, including through such notions as abuse of rights, imposes general restrictions on port state jurisdiction, as regards both prescription and enforcement. ${ }^{95}$ Furthermore, certain exercises of port state jurisdiction may not be consistent with international trade law, in particular the General Agreement on Tariffs and Trade (GATT) 1994, and possibly even the General Agreement on Trade of Services (GATS) 1994. ${ }^{96}$

In the current context, it is not unreasonable to argue that the landing prohibition in paragraph 25 of the 2000 STR Arrangement must be presumed to be consistent with current international law. The key element to this presumed consistency is that the high seas conservation and management measures have not been prescribed unilaterally. The fact that bilateral measures are not explicitly sanctioned by Article 23(3) of the 1995 Agreement is not necessarily problematic. The South Tasman Rise fishery is effectively a new fishery and paragraphs $30-32$ of the 2000 STR Arrangement envisage participation by more

Cont.

commit themselves to its exercise through para. 25. See also in the main text below on the issue of the multilateral character of conservation and management measures on the high seas.

94 E.g. CCAMLR Conservation Measure 118/XVII, in particular paras (4) and (5); NAFO's "Scheme to Promote Compliance by Non-Contracting Party Vessels with the Conservation and Enforcement Measures Established by NAFO" (NAFO/GC Doc. 97/6, www.nafo.ca; in particular paras (9) and (10)); and Art. 15 of the Draft SEAFO (South East Atlantic Fisheries Organization) Convention (6th Meeting, May 2000).

95 See, inter alia, Art. 300 of the LOS Convention; Art. 34 of the 1995 Fish Stocks Agreement; Churchill and Lowe, note 46 above at pp. 61 65; and Molenaar and Tsamenyi, note 33 above at pp. $98-104$.

96 Texts available at www.wto.org. 
countries. ${ }^{97}$ However, as is already argued more generally above, the consistency of the landing prohibition would ultimately depend on the way in which the concept of real interest is applied and to what extent participatory rights offered to new participants are equitable. ${ }^{98}$

More problematic than this landing prohibition are the consequences which New Zealand attaches to them. Pursuant to New Zealand's Fisheries (South Tasman Rise Orange Roughy Fishery) Amendment Regulations 1999,99 the prohibition to land orange roughy in New Zealand applies to "every person", punishable with a penalty not exceeding NZ\$100,000. ${ }^{100}$ Nothing in Article 23 of the 1995 Fish Stocks Agreement suggests that port state enforcement can go beyond inspection. ${ }^{101}$

In light of the current uncertainty on the scope and extent of port state jurisdiction under general international law, guidance from the global level would be welcome. ${ }^{102}$ One such opportunity could arise in the context of a dispute between Chile and the European Community (EC). The dispute concerns Chilean measures that prohibit the unloading of swordfish in Chilean ports. The measures are laid down in Decree 598 of 15 October 1999, which is established on the basis of Article 165 of the Fishery Law (Ley General de Pesca $y$ Acuicultura) of Chile, as consolidated by the Supreme Decree 430 of 28 September 1991. On 19 April 2000, the EC filed a complaint with the World Trade Organization (WTO) for inconsistency of these Chilean measures with the GATT 1994, in particular Articles v and XI, as they prevent Community vessels

As this latter element was lacking in the 1998 STR Arrangement, the consistency with current international law of the landing prohibition contained therein was certainly questionable.

98 See also note 114 below and the accompanying text. It must be observed, however, that an authority such as Churchill does not raise this argument in relation to Art. 7 of the Barents Sea Loophole $\Lambda$ greement (Agreement Betwcen the Government of Iceland, the Government of Norway and the Government of the Russian Federation Concerning Certain Aspects of Coopcration in the Area of Fisheries. St Petersburg, 15 May 1999, in force Summer 1999, text at (1999) 14 International Journal of Marine and Coastal Law 484 490). See Churchill, note 73 above at pp. 471,474 and 477.

99 SR 1999/142, in force 13 August 1999.

100 Regs 2 and 4 of the 1999 amendments, which inter alia amend regs 3 and $5(2)$ of the Fisheries (South Tasman Rise Orange Roughy Fishery) Regulations 1999.

101 M. Hayashi, "The 1995 UN Fish Stocks Agreement and the Law of the Sea" in D. Vidas and W. Ostreng (eds), Order for the Oceans at the Turn of the Century (The Hague, London and Boston, Kluwer Law International. 1999), pp. 37-5.3 at p. 46 mentions that the power to detain did not make it through the negotiation phase. It is also noteworthy that at the 4th Meeting in the SEAFO process (see note 94 above), a United States proposal on Art. 14 was not accepted. This would have allowed the port state to "detain the vessels for such reasonable period of time as necessary for enforcement purposcs" (para. (3); see para. (6) for mutatis mutandis application to fishing vessels of non-parties).

102 Note that paras 52-53 of the Sydncy Draft IPOA on IUU Fishing, note 7 above, referred to the possibility of initiatives at the global level to develop progressively the international law relating to port state jurisdiction. Para. 53 was deleted and para. 52 amended to such an extent that the original intention has disappeared (see para. 81 bis of the October 2000 Draft IPOA on IUU Fishing, note 7 above). 
from landing or transhipping swordfish in Chilean ports. A request by the EC to establish a WTO panel was honoured on 12 December $2000 .{ }^{103}$ Witness to the significance of the issues involved is the fact that a number of important States reserved their third-party rights. ${ }^{104}$ Subsequently, Chile proceeded with its plan to commence compulsory proceedings against the EC under Part XV of the LOS Convention. Later in December 2000, Chile and the EC agreed to submit the dispute to a special chamber of the ITLOS. 105

It will be interesting to see what role the recent adoption of the Framework Agreement for the Conservation of the Living Marine Resources on the High Seas of the Southeast Pacific (Galapagos Agreement) will play in these procedures. ${ }^{106}$ This Agreement was developed within the Permanent Commission for the South Pacific (CPPS) by Chile, Colombia, Ecuador and Peru. None of them has either signed or ratified the 1995 Fish Stocks Agreement. Even though states and entities like the EC, Japan and South Korea have traditionally been actively fishing in the area of application of the Santiago Agreement (Art. 3), they were not invited to participate in the negotiation of the Santiago Agreement. ${ }^{107}$ Article 16(3) of the Agreement nevertheless allows "other interested States" to accede one year after the Agreement's entry into force. This term is defined in Article 1(1.3) as "the States involved in distant-water fishing which have an established interest in specific fishery resources in this subregion, including qualified intergovernmental organisations". ${ }^{108}$ Moreover, Article 1(1.4) provides: "'Established interest': the interest demonstrated by a state whose nationals habitually fish for one or more fish populations within this Agreement's area of application and whose participation may fall within the scope of this interest." These concepts and their definitions considerably restrict the right to participate in the Santiago Agreement and have not been agreed to at the global level or elsewhere at the regional level.

Several other provisions of the Agreement also reflect a preferential status for the four coastal states. ${ }^{109}$ Furthermore, a highly relevant provision in the

${ }^{103}$ Active Panel No. 14. Chile - Measures Affecting the Transit and Importation of Swordfish, complaint by the EC (WT/DS193/1). See Art. 6 of the Understanding on Rules and Procedures Governing the Settlement of Disputes (Annex 2 to the WTO Agreement). Information available at www.wto.org, accessed 3 January 2001. Art. V of the GATT 1994 concerns the freedom of transit and Art. XI the general elimination on quantitative restrictions.

104 These are: Australia, Canada, Ecuador, India, Norway, Iceland and the United States.

105 Case Concerning the Conservation and Sustainable Exploitation of Swordfish Stocks in the SouthEastern Pacific Ocean (Chile v European Commumity), Constitution of Chamber. Order 2000/3 of 20 December 2000, text available at www.un.org/Depts/los.

${ }^{106}$ Santiago, 14 August 2000 , not in force. The EC has explicitly requested the ITLOS special chamber to rule on the Galapagos Agreement (ITLOS Order 2000/3, at p. 4, para. 3(f)).

${ }_{117}$ The issue is therefore arguably similar to the involvement of South Africa in the 2000 STR Arrangement.

108 The author is not entirely certain if the English translation of the Galapagos Agreement available to him is the official (and final) one, even though it was sent by the CPPS Secretariat.

109 See inter alia paras 5 and 9 of the preamble and Arts $5(1)(\mathrm{e}), 5(2)$ and 12. 
Santiago Agreement is Article 9 on "Measures to be adopted by port states". Its subparagraph (b) stipulates that states parties which are also port states shall adopt measures:

"To prevent disembarkation and ship-to-ship transfers when reasonable grounds exist to believe that captures of fish in the Agreement's area of application have been carried out in contravention of the rules and conservation measures adopted by the States parties, or, in the absence of such measures, when such captures have served to undermine the effectiveness of the measures in force with respect to the same fish populations in the coastal States' national jurisdiction zones."

Article 9(b) shows that the states that negotiated the Galapagos Agreement are keen to exercise port state jurisdiction in concert or, if need be, unilaterally. A real possibility therefore exists that ports along the entire South American coast will be closed to ships not flying the flag of states parties to the Galapagos Agreement. For several reasons this is more problematic than similar practices in other RFMMs. The envisaged prohibitions would be allowed in two situations: (1) in relation to measures that are adopted by the states parties, presumably collectively, that apply to the high seas; and (2) in relation to measures adopted by a coastal state for its own maritime zones (not the high seas). The first situation would be similar to paragraph 25 of the 2000 STR Arrangement. However, consistency with international law is certainly more questionable due to its negotiating history and the use of the terms "other interested States" and "established interest". The second situation appears to be an exercise of jurisdiction on the objective quasi-territorial principle, mentioned above. ${ }^{110}$ The legality of jurisdiction under this rather controversial principle would, inter alia, have to be assessed in light of the rights and interests of other states and by taking account of the principles of non-discrimination and reasonableness. A relevant consideration is that reliance on national measures becomes only pertinent in the absence of measures adopted by the states parties, presumably collectively. In the particular way in which Article 9(b) of the Santiago Agreement is worded, states parties have an obligation to rely on unilateralism where a multilateral approach is, for whatever reason, not forthcoming. It could be argued that this suggests that unilateralism is not perceived as a last resort.

Classification of the 2000 STR Arrangement and Other Alternatives to Flag State Jurisdiction

As the 2000 STR Arrangement does not establish an organisation, the question remains whether it can be classified as a regional fisheries management

${ }^{110}$ See the text accompanying note 92 above. 
arrangement in the sense of Article 1(1)(d) of the 1995 Fish Stocks Agreement.111 "Arrangement" is here defined as:

"a co-operative mechanism established in accordance with the Convention and this Agreement by two or more States for the purpose, inter alia, of establishing conservation and management measures in a subregion or region for one or more straddling fish stocks or highly migratory fish stocks."

The 2000 STR Arrangement would certainly qualify as an example of the loosely formulated term "co-operative mechanism". The other condition in this definition that could raise objections is that an arrangement should be "established in accordance with the Convention and this Agreement". It could be argued that this would depend on whether South Africa did indeed make a request to participate in the fishery on the South Tasman Rise after its vessels had engaged in fishing. ${ }^{12}$ If answered in the affirmative, Australia and New Zealand would not have acted fully consistently with Article 63(2) of the LOS Convention and Article 8(5) of the 1995 Fish Stocks Agreement. The former provision "merely" requires coastal states to co-operate with "States fishing" for straddling stocks on the high seas but the latter provision takes this one step further by requiring these states to establish an RFMM. ${ }^{13}$ As Australia and New Zealand expressed their shared intention of becoming parties to the 1995 Fish Stocks Agreement, the fact that Article 8(5) is not in force would not seem conclusive. Prima facie the argument could therefore be made that the 2000 STR Arrangement has not been established consistently with international law, at any rate vis-à-vis South Africa, and thus not opposable to it. ${ }^{114}$ Nevertheless, this

111 Churchill, note 73 above at pp. 476 and 482, takes the view that the Barents Sea Loophole Agreement (note 98 above) is not an arrangement within the meaning of Art. I(1)(d) of the 1995 Agreement, but rather an example of direct co-operation between coastal and high seas fishing states referred to in Arts 7(1)(a) and 8 of the Agrcement. A different question is whether the 2000 STR Arrangement should be regarded as a treaty. While this cannot be thoroughly addressed here, it should be observed that neither Australia nor New Zealand regard it as a treaty. The systematic use of "will" instead of "shall" supports this.

112 The situation of Belize is regarded as less relevant, mainly due to the fact that it did not make a request to participate. See note 89 above on the specific situation of South Africa.

113 See note 89 above for the issue of whether South Africa can be regarded as a "State fishing".

114 The EC, Japan and South Korca would be cntitled to a similar argument with respect to the Galapagos Agreement (see the section entitled "Port State Jurisdiction" above). It is worth noting that, during the Technical Consultation on IUU Fishing in October 2000, Japan requested the insertion of "relevant" before practically all references to "regional fisheries management organisations" (e.g. paras 12, 13, 13quater, 50 and 69 of the October 2000 Draft IPOA on IUU Fishing, note 7 above). In the view of the present author, it would have been better to include appropriate wording in the definition of RFMOs in para. 6 of the October 2000 Draft. It is quite likely that Japan's concerns were motivated by the Galapagos Agreement or its experience in the negotiation of the 2000 Honolulu Convention (see note 81 above). In the latter process, Japan and South Korca ultimately voted against the adoption of the Convention for the reason that their interests had not been duly taken into account. The EC was not even allowed to vote as it had not been admitted as a full participant in the negotiations, despite their repeated requests (see Molenaar, note 54 above). These examples indicatc that the argument could be 
shortcoming would be resolved vis- $\dot{a}$-vis South Africa if the latter made a request to become a party in accordance with paragraphs 30-32 of the Arrangement, ${ }^{115}$ and Australia and New Zealand considered this request taking due account of the concept of real interest and the need to ensure equitable participatory rights for all. South Africa would thereby accept the fact that it has lost an opportunity to contribute to the substance of the 2000 STR Arrangement. ${ }^{116}$ An alternative resolution for the identified defect would be for South Africa to officially withdraw its request for participation.

One of main innovatory features of the 1995 Fish Stocks Agreement is that it contains an important exception to the primacy of flag state jurisdiction on the high seas. ${ }^{117}$ Its Articles 21 and 22 allow a state party to the Agreement which is a member of, or participant in, an RFMM to take limited enforcement action over fishing vessels flying the flag of another state party to the Agreement, whether or not that state is a member of, or participant in, that RFMM. ${ }^{118}$ Classification of the 2000 STR Arrangement as an RFMM would therefore bring this appealing alternative to flag state jurisdiction into view. The reason for not incorporating this alternative in the Arrangement probably lies in the simple fact that the 1995 Fish Stocks Agreement has not yet entered into force and no other legal basis under general international law would be available. The Arrangement could of course be amended in the future.

Nevertheless, paragraphs 28 and 29 of the Arrangement provide for other alternatives to flag state jurisdiction. Paragraph 28 aims at seeking the cooperation of states in a variety of capacities, namely, as port, coastal or (potential) flag state, to ensure that vessels that undermine or threaten to undermine the effectiveness of the Arrangement cannot freely land or tranship their catch in ports or in a coastal state's maritime zones or reflag the vessel. In addition, paragraph 29 reads:

"Each Party will take all steps permitted by its domestic law to ensure that its nationals and companies do not engage in trawling or other demersal fishing in the high seas area of the South Tasman Rise with vessels not subject to the control of either of the Parties." 119

Cont.

made that, under certain circumstances, RFMMs as such are not established in consistency with international law, and not just vis-à-vis individual states.

115 See note 89 above.

${ }^{116}$ See also the observations on Southern Ocean Fisherics above.

117 This primacy is recognised in inter alia Art. 92 of the LOS Convention.

${ }^{118}$ Sec Art. 21(1). In accordance with Arts 21 and 22, enforcement action is in principle limited to boarding and inspection, but may extend to other enforcement measures such as bringing a vessel to a port (Art. 2l(8))

119 The meaning of the clause "not subject to the control of either of the Parties" is not entirely clear. Presumably, it denotes something broader than the control which flag states can exercise. Note that paras 26 and 27 also use complex formulae, perhaps due to the issuc of "countries" (see the section entitled "General Approach to Third Countries" above). 
The parties thus commit themselves to exercising jurisdiction under the nationality principle (also called the active personality principle), by which a state reaches out to its own nationals wherever they may be. Recent times have witnessed a growing interest in this jurisdictional principle for its potential use as an alternative to ineffective or unwilling flag states. ${ }^{120}$ It could even be argued that the references to "nationals" in Section 2, Part VII of the LOS Convention should be interpreted as an obligation to exercise jurisdiction under this principle. ${ }^{121}$ Despite its attractiveness, however, it is not devoid of controversy. As it often creates parallel jurisdiction, in this case with the flag state, ${ }^{122}$ states have in general tended to confine it to serious offences.

A more pressing problem is caused by the fact that international law gives states a wide margin of discretion in determining which natural persons are entitled to its nationality and what conditions legal persons (companies) must meet under its domestic law. It is worth recalling here that the wide discretion of flag states in setting conditions for the registration of ships, and thereby their nationality, is perceived as being intricately linked to bad flag state performance, even though the real issue is one of effective enforcement and control. This discretion is less problematic if states are really determined to exercise jurisdiction under the nationality principle. However, in addition to potential problems related to parallel jurisdiction, it raises a number of policy problems, for example how enforcement can be ensured and what extent of involvement of a company is sufficient. In light of these difficulties, it will be very difficult to compel less determined states to exercise this type of jurisdiction. The attractiveness of jurisdiction under the nationality principle, however, is that it would lead to a situation where illegal, unreported and unregulated (IUU) fishing is mainly carried out by vessels operated, owned or controlled by only few companies located in only few states and crewed by only few nationalities. This will enable focused and collective measures against these "rogue" companies and states.

${ }^{120}$ E.g. Art. 6 of the 1999 Barents Sea Loophole Agreement (note 98 above) and Art. 13(6)(a) of the Draft SEAFO Convention (note 94 above, 6th Meeting, May 2000). Paras 16-17, 25, 54, 61-62 and 75 of the Sydney Draft on IUU Fishing (note 7 above) were substantially weakened to become paras 13quater, 16, 16bis, 61-62 and 75 of the October 2000 Draft on IUU Fishing (note 7 above), where reference is now made to "nationals", which would allow states ample discretion in interpretation.

${ }^{121}$ Note that Art. 14 of the Convention on Fishing and Conservation of the Living Resources of the High Seas (Geneva, 29 April 1958, in force 20 March 1966. 559 UNTS 285) stipulates that: "In Articles $1,3,4,5,6$ and 8 , the term 'nationals' means fishing boats or craft of any size having the nationality of the State concerned, according to the law of that State, irrespective of the nationality of the members of their crews." As the LOS Convention docs not contain such a definition, the term "nationals" justifies a broader interpretation than merely vessels.

122 But more often with jurisdiction under the (quasi-)territorial principle. 


\section{Challenger Plateau}

Another interesting example of conservation and management of orange roughy concerns the stock on the Challenger Plateau, east of New Zealand. Catches occur mainly in two areas that both lie somewhat north of the $40^{\circ}$ parallel of south latitude. The first area is located 10-15 nautical miles within New Zealand's EEZ and the second area, the so-called "Westpac Bank Box", ${ }^{123}$ lies 25 nautical miles beyond the EEZ boundary on the high seas. ${ }^{124}$ In the early 1980s, fishing vessels registered in New Zealand commenced fishing for the stock on the Challenger Plateau. The Westpac Bank Box was targeted only at a later stage. In previous years, most of the catch was taken within New Zealand's EEZ. However, the Challenger Plateau TAC for the 2000-01 season, beginning on 1 October 2000 , has been set at one tonne, which means the fishery is effectively closed. On the same date, major TAC reductions in two other orange roughy fisheries in the maritime zones of New Zealand will also become effective. ${ }^{125}$

Research carried out by New Zealand suggests that the stock in these two areas is a straddling stock. In line with this, New Zealand manages the Challenger Plateau orange roughy stock as a single stock under its Quota Management System. A vessel registered in New Zealand must therefore count any orange roughy caught from this stock, whether inside or outside New Zealand's EEZ, against the same quotum. New Zealand has not adopted legislation that specifically applies to that part of the stock which is on the high seas, in the Westpac Bank Box.

As soon as the lucrative fishing grounds in the Westpac Bank Box became known, a number of other states, including Australia, Japan, Norway, South Korea and the Russian Federation, entered the fishery. Fearing a depletion of the entire Challenger Plateau stock, New Zealand urged these states to take appropriate conservation measures, preferably a voluntary moratorium. These concerns led, inter alia, to a single exchange of letters between officials of New Zealand and Australia, dated 26 June 1991. The New Zealand letter emphasises concern for the state of the orange roughy stock, the need for measures to address the situation and the consequent need for co-operation between the two states. It concludes with expressing the hope that the above is acceptable to Australia and that Australia's acceptance "will constitute an understanding between the Governments of Australia and New Zealand". The Australian letter effectively repeats the content of the New Zealand letter and confirms that its substance is acceptable. While the Australian

\footnotetext{
${ }^{123}$ The name "Westpac" rofers to a commercial bank with branches in Australia and New Zcaland. Fishermen apparently chose this name because fishing there was like "money in the bank"!

124 E. Meltzer, "Global Overview of Straddling and Highly Migratory Stocks: The Nonsustainable Nature of High Seas Fisheries", (1994) 25 Ocean Development and International Law 255-344 at 295.

125 These are the East Cape and Mid-East Coast fisheries (see the media statement by Minister of Fisheries P. Hodgson, 7 September 2000, available at www.scoop.co.nz/mason/stories/PA0009/ S00112.htm). Setting the TAC at zero would imply that all quotas are zero as well and thereby cause problems for the computer system.
} 
letter concludes there is an understanding, this does not amount to a specific commitment in terms of action on the part of Australia. ${ }^{126}$

Acknowledging the seriousness of the situation, Australia subsequently discouraged its fishing industry from operating in the Westpac Bank Box. What methods Australia used to achieve this is not entirely clear. Apparently, Australia saw no need to prescribe penalties, as it anticipated that there would be voluntary compliance. However, this Australian restraint in fishing and the exchange of letters referred to have led New Zealand to argue that there is at least a very strong expectation that the status quo in the Westpac Bank Box will not be disturbed. Australia denies that its behaviour amounts to a renunciation of its right to fish in the Westpac Bank Box, inter alia, by pointing out that it never made an official statement which could be interpreted as such a renunciation.

New Zealand has from time to time had direct contact with other states whose vessels were involved in fishing activity in the Westpac Bank Box and sought their voluntary co-operation not to fish in that area. By what means such voluntary cooperation was sought is unclear. At some time, however, foreign vessels that wished to fish in New Zealand's maritime zones were refused licences if they had fished for orange roughy in the Westpac Bank Box. ${ }^{127}$ This and perhaps other disincentives such as prohibitions of landings and transhipments in port may still be in force today. As the stock was depleted in the early years of fishing in the Westpac Bank Box, targeted fishing activity by foreign vessels no longer occurs.

Although New Zealand argues that the Challenger Plateau orange roughy stock is a straddling stock, it has seen no reason to manage it together with other states by way of an RFMM. Its regulatory efforts and disincentives for other states to engage in fishing in the Westpac Bank Box do not qualify as an arrangement in the sense of Article 1(1)(d) of the 1995 Fish Stocks Agreement, let alone as an organisation. However, New Zealand's obligations to co-operate in relation to straddling stocks do not compel it to establish an organisation or enter into an arrangement. Even Article 7(1)(a) of the 1995 Fish Stocks Agreement, after it has come in force, allows a state to seek direct co-operation instead. ${ }^{128}$ The difficult question nevertheless remains whether New Zealand's behaviour lives up to what could be expected of it under that alternative. In particular, has it acted "in good faith and with due regard to the rights, interests and duties or other states" and

${ }^{126}$ Cf. A. Bergin and M. Haward, "Australia's Approach to High Seas Fishing", (1995) 10 International Journal of Marine and Coastal Law'349-367 at 353.

127 Meltzer, note 124 above at p. 296.

128 The relevant phrase in Art. 7(1)(a) is: "either directly or through the appropriate mechanisms for co-operation provided for in Part III". Art. 8(1) (in Part III) essentially repeats this. However, Art. 8(5) basically urges "relevant coastal States and States fishing on the high seas" to establish an RFMM. This contradiction is not casy to explain, but it would seem that the options in Arts $7(1)$ (a) and $8(1)$ must prevail. Churchill, note 73 above at pp. 477 and 482 , also bases his reasoning on these latter provisions when he classifies the 1999 Barents Sea Loophole Agreement as an example of a direct cooperation that is not incompatible with the 1995 Fish Stocks Agreement. Art. 63(2) of the LOS Convention also retains these various options. 
consistent with the principle of non-discrimination? ${ }^{129}$ In light of the general nature of these obligations and the fact that not all relevant information is available, this is very difficult to determine.

\section{Southern Indian Ocean}

This orange roughy stock is located on the high seas in the southwestern part of the Indian Ocean, south of Madagascar but north of 45 degrees south latitude and close to Broken Ridge. Although vessels of various states, including the Russian Federation, had already been fishing in that area, relatively large-scale fishing operations began a few years ago by vessels flagged in Australia, New Zealand and South Africa. The (southern) winter of 2000 saw the involvement of Namibian vessels and probably also vessels flagged in the Russian Federation and China (PRC). Catches are expected to peak and fishing intensity is such as to pose a threat to the sustainability of the stock, possibly even due to interference with spawning. The catch is mainly landed in Port Louis (Mauritius) and Durban (South Africa). ${ }^{130}$ South Africa is conducting routine in-port inspections of landings. 131

In November 1999, Australia invited New Zealand and South Africa for some preliminary talks on the negotiation of an RFMM to manage the fishery. ${ }^{132}$ The three states proceeded from the presumption that the orange roughy stock is a discrete high seas stock. At the end of July 2000, Australia forwarded a draft text for an RFMO (regional fisheries management organisation) ${ }^{133}$ to New Zealand and South Africa for their consideration and comment. It was Australia's intention that, after an initial round of drafting, the draft RFMO would be lodged with the FAO in order for other states with a real interest to come

129 The citation is from Art. 8(2) of the 1995 Fish Stocks Agreement. Sec also Art. 119(3) of the LOS Convention.

130 "Rush for Roughy in Indian Ocean", Seafood International, June 2000; and "Roughy Bonanza in Indian Occan", (2000) 39 Fishing News International 1 and 3, No. 5. At the first meeting of the UNICPOLOS (note 7 above). M. Gianni of Greenpeace International expressed his concern about this situation.

131 South Africa allows landings of catch on the condition that the captain shows its licence, or declares that the vessel and its crew operate in full conformity with applicable legislation of the flag state, and declares in writing that his or her statements are true (for a similar approach see para. 46 of the Sydney Draft IPOA on IUU Fishing (note 7 above), which was deleted from the October 2000 Draft IPOA on IUU Fishing (note 7 above); and CCAMLR Conservation Measure 147/XIX (text available at www.ccamlr.org)).

132 The meeting between government officials took place in Hobart, on $8-9$ November 1999. It was inter alia proposed that the future RFMO's regulatory area would extend "eastward from the South African EEZ, covering the high seas area of the FAO Statistical Area 51 lying south of the Tropic of Capricorn and abutting the northern boundary of CCAMLR" (cited from a letter by G. Rohan, AFMA, 17 December 1999, sent out to various addressees following the abovementioned meeting; the letter bears the caption "Indian Ocean Trawl Fishing - Regional Management Discussions").

${ }^{133}$ See note 59 above. 
forward and participate in finalising the draft. ${ }^{134}$ Whether this approach had the full support of New Zealand and South Africa is not altogether certain.

The Australian-led discussions are only part of the picture, however. Parallel negotiations have been taking place as a consequence of the abolishment of the Indian Ocean Fishery Commission (IOFC) by Resolution $1 / 116$, as adopted by the FAO Council at its 116th Session in June 1999. The Resolution also sanctioned the wish of the former members of the Committee for the Development and Management of Fisheries in the Southwest Indian Ocean (SWIO), one of the four IOFC subsidiary bodies, to establish an Article XIV body under the FAO Constitution. This body would deal with non-tuna fisheries of common interest to island and mainland states of the region. ${ }^{135}$ With this objective, Kenya and the former members of SWIO, namely, Comoros, France, Madagascar, Mauritius, Mozambique, Seychelles, Somalia and Tanzania, first met in Mauritius in January 2000. At the second meeting in Madagascar in July 2000 , they decided in favour of the establishment of a South West Indian Ocean Fisheries Commission (SWIOFC) and recommended that an intergovernmental consultation be convened. This was expected to happen by means of a four-day meeting in La Réunion, currently planned for February 2001.

The most recent version of the draft Agreement for the Establishment of a South West Indian Ocean Fisheries Commission (draft SWIOFC Agreement) stems from the Madagascar meeting. The first paragraph of the preamble to this draft Agreement notes that the Commission is "to promote the sustainable development, conservation, rational management and best utilization of fisheries resources in the Region with special emphasis on fisheries targeted at non-tuna species". The Commission is to be an essentially "open" RFMM. ${ }^{136}$ Regional fisheries bodies (RFBs) established under Article XIV of the FAO Constitution are generally allowed to pursue a more interventionist role in fishery conservation and management, compared to those established under Article IV. Nevertheless, the extent to which Member States of these FAO RFBs are determined to pursue management and conservation policies is in the end of conclusive importance. Among other things in view of the envisaged

134 This intention was expressed by a press release on 21 June 2000 by W. Truss, the Australian Minister for Agriculture. Fisheries and Forestry (available at www.affa.gov.au/ministers/truss/ releases). Moreover, the letter mentioned in note 132 above contains the following passage: "It was accepted that any agreement must involve all parties with a real interest in the fishery. It was also accepted that the arrangements should be transparent and open to new entrants with a demonstrated real interest in the fishery. However, Australia would wish to ensure that 'real interest" can be adequately substantiated."

135 See Report of the 11 th Session of the IOFC (FAO Fisheries Report No. 598 FIPL/R598(Bi)), para. 4. Both this report and the text of the FAO Constitution are available at www.fao.org/legal.

${ }^{136}$ See Art. III of the Draft SWIOFC Agreement (Madagascar meeting). The seventh paragraph of the preamble refers to the relevance of the concept of real interest, but not the body of the Agreement. 
functions of the SWIOFC under Article IV(2)(b) of the draft SWIOFC Agreement, ${ }^{137}$ it is intended to be largely similar to a "regular" RFMO. ${ }^{138}$

An important decision made at the Madagascar meeting was to extend the "area of competence" to the high seas instead of limiting it to the maritime zones of the participating states. In addition to a more general wish to avoid high seas gaps, an awareness of the orange roughy fishery in the southern Indian Ocean and therefore of the possibility of other high seas, non-tuna fisheries, seems to have played a major role in this decision. The southern and western boundaries of this regulatory area now correspond to FAO Statistical Area No. 47. ${ }^{139}$ As a consequence, South Africa has become a coastal state in relation to the SWIOFC process and is expected to be invited to participate as such at the coming La Réunion meeting.

The complete picture therefore consists of two parallel negotiation processes, each aimed at the establishment of an RFMO that is very likely to have competence over at least some identical species in certain spatial areas. This appears to be a sheer coincidence as, until very recently, the two processes seem to have been unaware of each other. Whether the decision to extend the area of application of the draft SWIOFC Agreement was made without any knowledge whatsoever of the Australian-led process, however, is open to question. While the background of the Australian-led discussions is the demersal orange roughy fishery, the SWIOFC process is geared in a much broader way to non-tuna species in the envisaged area. An important difference between the two is that those that have so far participated in the SWIOFC process have done so

${ }^{137}$ See also the dispute settlement procedure in Art. XVII, which is clearly modelled on Part VIII of the 1995 Fish Stocks Agrement. Art. IV(2)(b) provides that the Commission shall recommend appropriate measures regarding, inter alia, the:

- conservation and rational management for shared and transboundary stocks or resources throughout their range, including measures:

- regulating fishing methods and fishing gear,

- prescribing the minimum size for individuals of specified species,

- establishing open and closed fishing seasons and arcas,

- regulating the amount of total catch and of fishing effort and their allocation among Members,

- establishment of effective Monitoring, Control and Surveillance systems and discouraging vessels flying flags of non-members or non-participants from engaging in activities that undermine the effectiveness of conscrvation and management measures."

138 Consistent therewith, the preamble to FAO Council Resolution $1 / 116$ notes that "at its Hundred and Twelfth Session in June 1997, the Council, in adopting the report of the Twenty-second Scssion of the Committee on Fisheries, stressed the need for effective regional fishcry organizations and arrangements and agreed that FAO regional fishery bodies should be reviewed and evaluated with a view to strengthening them". The fut ure SWIOFC is expected to be largely modelled on the Indian Ocean Tuna Commission (IOTC).

139 Art. II of the Draft SWIOFC Agreement (Madagascar meeting). The western and southern boundaries have been chosen to coincide with the northern boundary of the CCAMLR Convention (Convention on the Conservation of Antaretic Marine Living Resources, Canberra, 20 May 1980, in force 7 April 1982, www.ccamlr.org) and the eastern boundary of the Draft SEAFO Convention (note 94 above, 6th Mecting, May 2000; see Art. 4), thereby also avoiding gaps or overlaps. 
primarily in their capacities as coastal states, but those in the Australian-led discussions have done so primarily as flag states. The latter process deals exclusively with discrete high seas stocks and, if it led to the establishment of an RFMO, it would be the first of its kind. ${ }^{140}$ As such, it would in principle not be governed by the 1995 Fish Stocks Agreement, irrespective of its entry into force, but instead by Section 2, Part VII of the LOS Convention. The obligations incorporated therein are rather broadly formulated and give much less guidance in comparison with the 1995 Fish Stocks Agreement.

The Australian-initiated RFMO would thus be breaking new ground. ${ }^{141}$ This does not mean that certain provisions or principles of the 1995 Fish Stocks Agreement may not, mutatis mutandis, be applicable: for instance, Articles 5 and 6 in general, and in particular Article 6(6) on the precautionary approach towards new and exploratory fisheries, or the concept of real interest. The need for compatibility between high seas and EEZ management and conservation will at any rate not be relevant. Other aspects may be applied on a voluntary basis, as long as this does not affect the rights of third states.

The fact that these two processes were until quite recently unaware of each other naturally raises questions on transparency. This does not necessarily imply deliberate policies of secrecy to safeguard interests but at any rate it suggests insufficient publicity combined with a lack of communication between and within national governments. ${ }^{142}$ One of the clear consequences of this lack of transparency is that certain states (i.e. those with a real interest) may not be invited to participate from the outset, and thereby have less opportunity to contribute to the creation of the RFMO, or none at all. The question is of course what can be expected of those that initiate processes to establish RFMMs. To an important extent this depends on the interrelated issues of the stocks that are to be managed, the intended type of management and the intended spatial coverage of the regulatory area. Often, a wide range of other considerations also plays a role. ${ }^{143}$ Due to the uncertainty surrounding the concept of real interest and the

141) The Draft SEAFO Convention (note 94 above, 6th Meeting, May 2000) includes discrete high seas stocks within its scope (sce the definition of "fishery resources" in Art. 1(1) coupled to the definition of the Convention Area in Art. 4).

141 Para. 81 of the Sydney Draft IPOA on IUU Fishing (note 7 above) calls upon the FAO and states to "consider the elaboration of obligations under Part VII of the [LOS Convention], in particular the elaboration of obligations relating to high seas stocks other than straddling fish stocks or highly migratory fish stocks". Grecnpeace International has proposed amending para. 25 of the Sydney Draft in order that states should (a) manage discrete high seas stocks "at a minimum consistent with" Arts 5 and 6 of the 1995 Fish Stocks Agreement, (b) "prevent ... fishing on such stocks until an effective regime is in place" and (c) "prevent ... fishing in a manner likely to adversely impact ecologically sensitive areas". In the October 2000 Draft IPOA on IUU Fishing (note 7 above), para. 81 has been deleted altogether while the amendments proposed by Greenpeace were not incorporated.

142 See, however, note 134 above and note 149 bclow.

143 C. Molenaar, note 54 above, inter alia in the section entitled "Spatial Scope of the RFMM's Regulatory Arca". 
ensuing difficulty in determining who should be invited, it is in principle not objectionable to leave the initiative to others. ${ }^{144}$ An important proviso is that other states are, in due time, able to ascertain the existence of these processes and express their interest to become involved. This essentially passive attitude may very well be justifiable for vulnerable stocks such as orange roughy, where time for extended negotiation processes is simply lacking and immediate measures are needed.

The considerations that would be relevant to the SWIOFC process are clearly different from those for the Australian-led process. With respect to the former, it is notable that participation in the two meetings held so far was limited to certain coastal states. Why South Africa was not among them is not entirely clear, but that is now resolved due to the changed area of application. At the Madagascar meeting, it was also realised that, apart from inviting South Africa as a coastal state, certain flag states would have to be invited as well. ${ }^{145}$ At the moment of writing this had not been done yet (see below). As regards the Australian-led process, states that were already involved in fishing during the negotiations or preliminary discussions, such as Namibia, should arguably have been invited in any case. ${ }^{146}$ The same probably holds for coastal states that are very near to the fishing grounds and especially if landings take place in their ports, such as Mauritius. ${ }^{147}$ It may not be altogether hypothetical that the hesitation to invite certain coastal states has influenced the extension of the regulatory area under the draft SWIOFC Agreement.

The most recent development took place on 29 October 2000, in Hobart, where an informal meeting on the "South Indian Ocean Demersal Fishery" took place. The composition of participating states was more or less coincidental as the meeting was conveniently held during the Nineteenth Annual Meeting of the Commission on the Conservation of Antarctic Marine Living Resources (CCAMLR). ${ }^{148}$ The purpose of the meeting was to resolve the problems caused

144 See the section entitled "General Approach towards Third Countries" above.

${ }^{145}$ This is apparently expressed in the still unpublished report of the Madagascar mecting.

146 In the letter-exchanges at ministerial level between Australia and Namibia (note 89 above), the latter explicitly claims to have a real interest in relation to deepwater stocks in the south-west Indian Ocean and requests to become involved in a management regime. Its situation is therefore rather similar to that of South Africa in relation to the 2000 STR Arrangement (see the section entitled "Classification of the 2000 STR Arrangement and Other Alternatives to Flag State Jurisdiction" above and note 148 below). By contrast, motivated by the wish to establish an "open" RFMO, the coastal states that initiated the SEAFO process invited those states that were "identified as having distant water fishing interests in the region" and those that were fishing in the prospective regulatory based on FAO fishing data (Record of Proccedings, 4th Meeting, "Brief Summary of the SEAFO Process Prepared by the UK Chair").

147 It is noteworthy that the CCAMLR puts in a lot of effort in trying to get Mauritius involved, whether or not as a party, due to the fact that Port Louis is an important port of landing for Dissostichus eleginoides or Dissostichus mawsoni (toothfish).

148 Representatives came from: Australia, the EC, the FAO, France, Japan, Mauritius, New Zealand, Norway, South Korea, South Africa, Spain and Ukraine. The representative from South Africa noted that, among other interested states, Namibia should be invited to take part 
by the parallel processes and to participate constructively in a single process. Much of the discussion therefore centred on the upcoming La Réunion meeting, which was originally intended to adopt the SWIOFC Agreement. As most participants in Hobart had never been involved in the SWIOFC process before, they not only wanted an opportunity to participate but also questioned the possibility of concluding the SWIOFC process at the La Réunion meeting. ${ }^{149}$ The meeting eventually encouraged the FAO that, in sending out invitations to the La Réunion meeting, it would "ensure broad coverage (for example to include all FAO members and members of adjacent commissions) with a view to ensuring all those with a possible interest in the matter would be provided with a reasonable opportunity to participate". 150

According to the most recent information (mid-November 2000), the FAO has ascertained that, based on FAO fishing data, the following flag states have been engaged in fishing for non-tuna species in the envisaged regulatory area during the last five years: Australia, China, Italy, Japan, Lithuania, Namibia, New Zealand, Norway, Portugal, South Korea, Spain, the Russian Federation and Ukraine. ${ }^{151}$ Invitations will be sent out accordingly. ${ }^{152}$

As the SWIOFC process is essentially in its final stages, the question is to what extent there still is a genuine possibility of combining the two processes. To what extent are the states involved in the SWIOFC process prepared to have more meetings and reopen negotiations and to what extent are other states prepared to accept just one or two rounds of negotiation and certain issues as non-negotiable? Where the SWIOFC process would not pay due regard to the interests of states that have not participated so far, it runs the risk of not being established in consistency with international law or be confronted with a parallel RFMM.

Finally, an interesting aspect of the management of the orange roughy stock is caused by the claim by Kailis \& France, a multinational fishing operator, to have been the first to locate the stock and that considerable investments had to be made

Cont.

in the SWIOFC process. This information is based on a report by G. Rohan, Chair of the Meeting, of 1 November 2000. Mr Rohan kindly provided this report to the author. According to its first section, the report "could be made available to the FAO and to any interested party".

149 These observations indicatc that the report of the Madagascar meeting, which recommends the FAO to send out invitations to flag states, was not available yet. Implicit concerns on the objective of the La Réunion mecting are, for instance, also reflected in the fact that New Zealand tabled a background paper relating to the principles/issues to be considered in the development of the SWIOFC. Moreover, Australia suggested that there may be advantages in broadening the proposed regulatory area to include waters from southern Africa to Australia. This would then avoid the need to establish another RFMO to deal with non-tuna species in the Indian Ocean (Hobart Report, note 148 above at pp. 2-3).

150 Hobart Report, note 148 above at p. 3. It is noteworthy that no reference is made to "real interest" here, whereas this was still done in Section 1, on p. 1.

${ }^{151}$ This approach is thus similar to the one followed in the SEAFO process (note 146 above). The period of five years would seem to amount to an interpretation of the concept of real interest.

152 This implies that the EC will represent Italy, Portugal and Spain. 
to achieve this. Others apparently contest this by pointing out that the stock was incidentally fished already many years ago. Kailis \& France, which is using Australian-flagged vessels to exploit the stock, may nevertheless argue that its investments entitle it to some kind of preferential treatment in allocation. In light of applicable Australian policy, this is probably a sound argument vis-à-vis Australia. ${ }^{153}$ However, it is not persuasive vis-ä-vis other states, including New Zealand and South Africa in the Australian-led discussions or the states involved in the SWIOFC process. Unlike the international legal regime for deep sea-bed mining in the LOS Convention, the regime for high seas fisheries in the LOS Convention does not recognise a special interest for so-called "pioneer investors". 154 At first sight, it seems therefore that elements such as catch-history and fishing practices would be one of the main considerations for allocation. ${ }^{155}$

\section{Conclusions}

International law requires states to co-operate in the management and conservation of all three stocks of orange roughy discussed in this article. In each of these, co-operation has taken a different form. This is due to the specific characteristics of each case and the large measure of discretion which states have in this respect. International law does not rigidly dictate how co-operation should take place, even though the 1995 Fish Stocks Agreement expresses a stronger preference for co-operation through regional fisheries management mechanisms (RFMMs) as compared to the LOS Convention.

International law is currently unable to offer sufficient guidance for categorising stocks as straddling (EEZ-high seas), shared (EEZ-EEZ) or discrete (high seas or one EEZ). The conflicting views on the characterisation of the stock on the South Tasman Rise ensue directly from this shortcoming.

Kailis \& France has obtained an Australian fishing permit to begin an exploratory fishery and is thereby guaranteed access plus a minimum level of ongoing rights to any fishery which develops following an exploratory fishing phase. These preferential rights apply first of all within the AFZ, but in certain cases also beyond where the AFMA has jurisdiction (sce "Exploration of Fish Resources", Fisheries Management Paper No. 5, AFMA, May 1999; entry into force 13 May 1999; see Section 2.1 for its scope and Sections 2.3, 6.3, 7.3 and 8 for incentives).

154 See Part XI of the LOS Convention, Resolution II Governing Preparatory Investment in Pioneer Activities Relating to Polymetallic Nodules (adopled logether with the LOS Convention) and the Agreement Relating to the Implementation of Part XI of the United Nations Convention on the Law of the Sea of 10 December 1982 (UN General Assembly Resolution 48/263, 28 July 1994, in force $28 \mathrm{July} \mathrm{1996,} \mathrm{UN} \mathrm{Law} \mathrm{of} \mathrm{the} \mathrm{Sea} \mathrm{Bulletin,} \mathrm{special} \mathrm{issue}$ IV (1994), p. 8). At the Third United Nations Conference on the Law of the Sea (UNCLOS III), Lebanon and Mexico proposed that high seas fishing should be regulated similar to deep sea-bed mining, but these proposals found no support (see Orrego Vicuña, note 42 above at p. 10). As such pioneering activities may nevertheless be in the interests of the international community, a case could be madc for devcloping a legal regime which recognises the special interests of pioneer investors in high seas fisheries. Preferential treatment of pioneer investors, in whatever form, might be justified under Art. 119(1)(a) of the LOS Convention if it would lead to a higher maximum sustainable yield (MSY). See the policy adopted by Australia, note 153 above.

155 See the section entitled "Allocation" above. 
Scientific research, inter alia on genetics and population dynamics, may be able to make an important contribution to resolving or minimising these uncertainties. In the interim period, the precautionary approach both supports and reinforces the need to presume that transboundary effects occur and that, consequently, co-operation and interim management are needed to minimise a threat to the sustainability of the stock(s).

The exploitation of the orange roughy stock in the southern Indian Ocean is possibly the first instance where a need is felt to establish a co-operative mechanism that deals exclusively with discrete high seas stocks. The efforts by Australia, New Zealand and South Africa are commendable in view of the threat to the sustainability of the stock. Despite the fact that the 1995 Fish Stocks Agreement is not applicable, even if it would have been in force, it is argued that a number of its provisions should be applicable mutatis mutandis, for instance Articles 5 and 6 in general, and in particular Article 6(6) on the precautionary approach towards new and exploratory fisheries, or the concept of real interest. To decide otherwise would imply that discrete high seas stocks do not benefit from the progressive development of the international law relating to the conservation and management of marine living resources. It is in the international community's interest that such an opportunity is not lost.

The 2000 STR Arrangement reflects the pro-active attitude of Australia and New Zealand by its anticipatory implementation of various aspects of the 1995 Fish Stocks Agreement and by incorporating the latest regulatory tools used by other RFMMs to address illegal, unreported and unregulated (IUU) fishing. Compared to its 1998 predecessor, the 2000 STR Arrangement is a more permanent mechanism with many specific and detailed improvements to ensure stricter compliance. One of the many interesting innovations is a procedure for integrating new participants. This ensures that measures against non-participants are in principle legitimate (or consistent with international law) and is also more generally conducive to the long-term stability of the Arrangement.

New Zealand's approach to managing the orange roughy stock on the Challenger Plateau is fundamentally different. The various bilateral contacts between New Zealand and other states may amount to direct co-operation as an alternative to co-operation by means of an RFMM. However, insufficient information is available to determine if New Zealand's behaviour lives up to what could be expected of it under that alternative. A significant disadvantage of approaches like those pursued by New Zealand are their non-opposability to third states. Arguably, the mere existence of an RFMM gives more prima facie indication that non-participants are not discharging their obligations to cooperate under international law. This may be treated as a significant factor should participants in RFMMs decide to commence proceedings under Part XV of the LOS Convention, among other things to file a request for provisional measures under Article 290(5).

The manner in which RFMMs and negotiation processes to establish them deal with participation has important consequences for their legitimacy (or 
consistency with international law) and stability. For a variety of reasons, new participants are not necessarily always welcome. In the negotiating phase, a smaller group may cause fewer conflicts and lead to less protracted negotiations. Moreover, new participants may weaken the relative impact of the other states on the substance of the RFMM's constituting instrument and perhaps even their prospects on allocation. These considerations could to some extent explain why South Africa was not involved in the negotiation of the 2000 STR Arrangement and why more states were not involved at an early stage in the two parallel negotiation processes in the southern Indian Ocean, namely, the Australian-led process and the negotiation of the Agreement on a South Western Indian Ocean Fisheries Commission (SWIOFC). ${ }^{156}$ The crucial question is nevertheless what can be expected of states that initiate negotiation processes. It is submitted that some leeway is acceptable in light of the uncertainty surrounding the concept of real interest (where applicable) and the need for expeditious action to protect vulnerable stocks like orange roughy. An important proviso would nevertheless be that processes are sufficiently transparent and publicised to enable other states to express their interest to become involved. Where processes overstep these limits, however, the argument could be made that the RFMM has not been established in consistency with international law, at any rate vis-à-vis states whose real interest is beyond dispute and in particular if they have made a request to become involved.

States co-operating in already existing RFMMs may not be overly enthusiastic about new participants as this often leads to broader sharing of the TAC. Refusing participation to states with a real interest will nevertheless render the RFMM's measures inconsistent with international law and thus not opposable to those states. Moreover, non-participants (but not new entrants) will in general undermine the effectiveness of the RFMM. This not only concerns flag states but also coastal states and port states close to the fishing grounds. From the perspective of non-participants, allocations offered should often simply outweigh the impact of the various measures taken against them, such as blacklisting, port state jurisdiction and trade-related measures. RFMMs may also have specific characteristics that give participants more leverage. For example, the relative proximity to fishing grounds coupled to vigorous port state jurisdiction has significant implications for fishing operations (e.g. fuel or freshness of fish or fish products). Participation by others may also not be economically viable due to the size of the fishery or due to the fact that no complementary access to the maritime zones of coastal states can be obtained. ${ }^{157}$

The issues of participation and allocation are of crucial importance to an

\footnotetext{
156 This may also explain why the EC, Ecuador and Mexico were denied full participation in the negotiations of the 2000 Honolulu Convention (note 81 above). See Molenaar, note 54 above at the section entitled "The MHLC process".

157 This latter aspect may explain the attitude in the MHLC process (sce note 156 above).
} 
RFMM's legitimacy and (long-term) stability. Whereas these may be two distinct issues at a fundamental level, in reality they are strongly related. As a widely accepted interpretation of the concept of real interest and precise and generally applicable allocation criteria or practices are lacking, it must be concluded that international law can offer only little guidance. Scientific research may have a role to play in giving effective content to the concept of zonal attachment in order to provide more consistency and predictability to allocation practices. Another solution to these interrelated dilemmas of participation and allocation are package deals. This may be opportune for this article's case studies, as they often concern the same states. In fact, the 2000 STR Arrangement makes several references to broader co-operation in the Tasman Sea, which could inter alia include the South Tasman Rise and the Challenger Plateau and newly found stocks. Package deals could also relate to issues that are not directly related to one of the other case studies, or not even related to fisheries. The fundamental problem of package deals, namely, their non-opposability to third states, nevertheless remains. 


\section{Appendix}

\section{Arrangement Between the Government of Australia and the Government of New Zealand for the Conservation and Management of Orange Roughy on the South Tasman Rise}

The Government of Australia and the Government of New Zealand (the Parties):

Considering their shared commitment to the implementation of the relevant provisions of the United Nations Convention on the Law of the Sea 1982 and their shared intention to become parties to the United Nations Agreement on Straddling Fish Stocks and Highly Migratory Fish Stocks 1995 (the 1995 Agreement);

Affirming their shared concern for and commitment to the conservation of the living resources of the high seas;

Noting their previous Arrangements for the conservation and management of orange roughy on the South Tasman Rise;

Recognising the need for conservation and management measures to be maintained for South Tasman Rise orange roughy, and for those measures to be implemented at the domestic level by the Parties through effective and binding legislative controls;

Affirming the obligation to apply the precautionary approach widely to conservation, management and exploitation of fish stocks;

Mindful of the need to achieve as soon as possible an agreed understanding of the stock structure and abundance of orange roughy and other species taken on the South Tasman Rise;

Recognising also the need for continued scientific research on the status of orange roughy on the South Tasman Rise;

Acknowledging that the methodologies developed through a scientific research program for orange roughy on the South Tasman Rise, including mutually acceptable criteria for determining whether or not a stock is a straddling stock, will assist in broader assessments of orange roughy stock characteristics in the Tasman Sea region;

HAVE REACHED AN UNDERSTANDING on the following:

\section{Definitions}

1. For the purposes of this Arrangement:

annual catch limit in relation to a season means the whole-weight tonnage of orange roughy that a Party may take in that season in accordance with the formula in paragraphs 7 and 8 ;

Australian fishing zone (AFZ) has the same meaning as in the Fisheries Management Act 1991 (Cth);

high seas area of the South Tasman Rise means the area lying outside of and adjacent to the AFZ in waters generally south of Tasmania and enclosed by the line:

(a) commencing at the point $48^{\circ} 30^{\prime \prime} \mathrm{S}, 150^{\circ} \mathrm{E}-1$

(b) running thence west along the parallel of latitude $48^{\circ} 30^{\prime \prime} \mathrm{S}$ to the point $48^{\circ} 30^{\prime \prime} \mathrm{S}$, $146^{\circ} 30^{\prime \prime} \mathrm{E}$

(c) thence north along the meridian of longitude $146^{\circ} 30^{\prime \prime} \mathrm{E}$ to its first intersection by the outer limit of the AFZ;

Geographical coordinates in this definition are in terms of the International Terrestrial Reference System which is maintained by the International Earth Rotation Service and for most practical purposes are equivalent to coordinates in terms of the World Geodetic System 1984 (WGS84). 
(d) thence generally easterly and north-easterly along the outer limit of the AFZ to its first intersection by the meridian of longitude $150^{\circ} \mathrm{E}$;

(e) thence south along that meridian to the point of commencement;

quota in relation to a Party means the whole-weight tonnage of orange roughy in a season

that is allocated to the Party in accordance with paragraphs 5 and 6 ;

season in relation to a year means a period of 12 months beginning on 1 March of that

year and ending on the last day of February of the following year;

South Tasman Rise means the geomorphological feature as depicted on the map at Annex A.

Trawling and other demersal fishing only with authorisation

2. The Parties will prohibit trawling and other demersal fishing for all species on the high seas area of the South Tasman Rise except with the authorisation of the appropriate authorities in accordance with their respective national legislation, such authorisation only to be given for the purposes of implementing this Arrangement and subject to its terms.

\section{Total allowable catch}

3. Subject to any variation decided in accordance with paragraph 4 , the precautionary total allowable catch (TAC) for each successive season for the duration of this Arrangement is two thousand four hundred (2400) tonnes whole weight.

4. The Parties may, taking into account the outcomes of the scientific research undertaken under this Arrangement and any other relevant circumstances, decide to vary the TAC from time to time. Such a variation will be effected by an exchange of Ministerial letters between the Parties.

\section{Party quotas}

5. The TAC is allocated between the Parties in the following proportions:

Australia - 1800 tonnes, being seventy-five per cent $(75 \%)$ of the TAC

New Zealand -600 tonnes, being twenty-five per cent $(25 \%)$ of the TAC.

6. If the TAC is varied in accordance with paragraph 4 , the Parties' quotas will remain in the same proportions as set out in paragraph 5 , unless otherwise decided by the Parties and recorded in an exchange of Ministerial letters.

\section{Annual catch limits}

7. Unless the Parties jointly decide otherwise and record it in writing, a Party's annual catch limit for the 2000 season is equal to its quota. In each subsequent season, unless the Parties jointly decide otherwise and record it in writing, a Party's annual catch limit is calculated as follows:

(a) by adding to its quota for that season the amount, rounded to the nearest tonne, by which its catch in the previous season fell short of its annual catch limit, up to a maximum of five per cent $(5 \%)$ of its quota in the previous season, unless the TAC for that season is less than the TAC for the previous season; or

(b) by debiting against its quota for that season catch, rounded to the nearest tonne, taken by it in excess of its annual catch limit for the previous season (its excess catch) as follows: 
(i) one tonne to be debited for each of the first 100 tonnes of excess catch; and

(ii) two tonnes to be debited for each tonne of excess catch thereafter.

8. If a Party's quota for any season is insufficient to absorb the amount to be debited under paragraph 7(b), the Party concerned will debit any remaining amount against its quota for the following season, and any subsequent seasons as may be required.

9. Orange roughy caught in the high seas area of the South Tasman Rise will be debited against the annual catch limit of the Party that authorised the fishing irrespective of where the catch was landed.

\section{Implementation}

10. Each Party will implement this Arrangement through binding legislative or administrative mechanisms and will inform the other Party in writing of these mechanisms and of their entry into force. In particular, each Party will ensure that its annual catch limit is implemented in accordance with this paragraph with effect from the date of commencement of the relevant season.

11. Each Party will provide in its mechanisms pursuant to paragraph 10 that, when its annual catch limit for orange roughy in any season is reached, the high seas area of the South Tasman Rise is closed to all trawling and other demersal fishing for all species by its vessels for the remainder of that season.

\section{Program of scientific research}

12. The Parties will carry out a program of scientific research for the purposes of:

(a) obtaining information to enable an assessment of the size of the stock(s) of orange roughy on the South Tasman Rise and of the sustainable yield; and

(b) providing further information on the stock structure and relationship between orange roughy found in the high seas area of the South Tasman Rise and orange roughy found within the AFZ.

13. Any fishing undertaken within the scientific research program will be taken within the TAC.

14. The Parties will develop a framework for the collection and collaborative analysis of scientific information on orange roughy and other related stocks on the South Tasman Rise, based on the scientific program instituted by the Parties under their previous Arrangements. The program will be reviewed on an annual basis and where necessary amended to achieve its purposes.

15. The Government of Australia will ensure that for scientific and management purposes information is made available from scientific research programs into orange roughy and associated species undertaken on that part of the South Tasman Rise lying within the AFZ consistent with the scientific research program being carried out in the high seas area of the South Tasman Rise.

16. The Parties will ensure that their respective vessels authorised to fish on the South Tasman Rise collect and provide the data and samples required by the scientific research program.

\section{Exchange of information}

17. Without prejudice to any other arrangements between the Parties, the Parties will exchange at least on a weekly basis all relevant catch and effort information relating to orange roughy and associated species in the high seas area of the South Tasman Rise 
when trawling and demersal fishing is occurring and until the fishery is closed. Each Party will notify the other Party in writing of the position whose occupant for the time being is responsible for the exchange of information under this paragraph.

18. The Government of Australia will advise the Government of New Zealand of the management measures and any changes to the management measures for orange roughy and associated species it has adopted within the area of the AFZ adjacent to the high seas area of the South Tasman Rise. Aggregated catch data on such species will be provided on a three-monthly basis.

\section{Confidentiality}

19. Information exchanged pursuant to this Arrangement regardless of its form will be treated as being supplied in confidence and no information will be used except in the manner permitted by the supplying Party and subject to the freedom of information and privacy laws applicable to each Party.

\section{Monitoring}

20. Each Party will ensure that its respective vessels authorised under this Arrangement to fish in the high seas area of the South Tasman Rise:

(a) operate satellite-based vessel monitoring systems (VMS) during any trip involving fishing in that area;

(b) when fishing in that area report their position to their national authorities on at least a daily basis;

(c) when fishing in that area report their catch to their national authorities on at least a daily basis and on a shot-by-shot basis once seventy-five per cent $(75 \%)$ of that Party's annual catch limit has been taken;

(d) retain on board all catch taken in that area unless required by their national authorities not to do so;

(e) record catch in official log books on a shot-by-shot basis; and

(f) are notified immediately of the closure of that area to trawling and other demersal fishing.

21. Each Party will place observers on its own vessels at a level of coverage sufficient to ensure:

(a) the effective operation of the scientific research program;

(b) the effective implementation of the terms of this Arrangement, including adequate and timely verification of catch data; and

(c) where a vessel fishes both the high seas area of the South Tasman Rise and one or more other areas on a single trip, verification of the catch of orange roughy taken from the high seas area of the South Tasman Rise.

22. Each Party will ensure that its appropriate authorities monitor the dockside unloading of catch at a level of coverage jointly decided by the Parties to be sufficient to ensure the effective implementation of the terms of this Arrangement.

23. The Parties will ensure that no transhipment at sea of catch taken in the high seas area of the South Tasman Rise is permitted within waters under their national jurisdiction or to or from their fishing vessels or fish carriers. 


\section{Landings and port access}

24. Each Party's national arrangements in relation to access to its ports and landing there of catch taken by a vessel authorised to fish by the other Party will continue to apply for the purposes of this Arrangement.

25. Each Party will prohibit vessels not authorised under this Arrangement to fish in the high seas area of the South Tasman Rise from landing in its ports orange roughy and associated species taken in the high seas area of the South Tasman Rise.

\section{Co-operation}

26. The Parties will co-operate in the surveillance of, and immediately exchange information on, fishing activities in the high seas area of the South Tasman Rise by vessels of third countries not signatories to this Arrangement and by vessels of the Parties not authorised to fish there.

27. Following consultation, the Parties will, where practicable jointly, approach the flag state of a vessel from a third country that by fishing in the high seas area of the South Tasman Rise undermines or threatens to undermine the effectiveness of this Arrangement, with a view to seeking that country's co-operation in the conservation and management of orange roughy on the South Tasman Rise.

28. Following consultation, the Parties will, where practicable jointly, approach other countries with a view to deterring activities of vessels that undermine or threaten to undermine the effectiveness of this Arrangement. Such approaches will include seeking those countries' co-operation in deterring:

(a) landing in their ports, and transhipment in waters under their jurisdiction, of orange roughy caught in the high seas area of the South Tasman Rise; and

(b) transfer to the registers of those countries of such vessels.

29. Each Party will take all steps permitted by its domestic law to ensure that its nationals and companies do not engage in trawling or other demersal fishing in the high seas area of the South Tasman Rise with vessels not subject to the control of either of the Parties.

\section{Third countries}

30. The Parties will co-operate with third countries which have a real interest in the conservation and management of orange roughy on the South Tasman Rise with a view to securing the application by them of the conservation and management measures of this Arrangement.

31. The Parties will jointly consider in terms of Article 11 of the 1995 Agreement any request by a third country referred to in paragraph 30 to become a Party to this Arrangement.

32. The inclusion of any new Party in this Arrangement will be effected by an appropriate instrument signed by all Parties which confirms the acceptance by the new Party of the understandings set out in this Arrangement and sets out the participatory rights of the new Party.

\section{Commencement and duration}

33. This Arrangement takes effect on 1 March 2000. Any Party wishing to end this Arrangement will notify the other Party, at least 12 months in advance, of the date on which it is to cease. 


\section{Miscellaneous}

34. Should any misunderstandings or differences arise between the Parties on the interpretation or implementation of this Arrangement, they will consult at the request of either of them with a view to resolving matters amicably and without unreasonable delay.

35. The Parties will jointly lodge this Arrangement with the Fisheries Division of the United Nations Food and Agriculture Organization for the purposes of international publicity.

36. This Arrangement is without prejudice to any future arrangements or agreements the Parties may enter into with respect to Tasman Sea fisheries generally or orange roughy on the high seas area of the South Tasman Rise.

This Arrangement embodies the understanding reached between the Parties concerning fisheries matters in the high seas area of the South Tasman Rise.

(The signatures for the Government of Australia (date 25 February 2000) and for the Government of New Zealand (date 17 February 2000) have been omitted.) 